\title{
Revision of the Australian millipede genus Pogonosternum Jeekel, 1965, with descriptions of two new species (Diplopoda, Polydesmida, Paradoxosomatidae)
}

\author{
Peter DECKER ${ }^{1, *}$, Robert MESIBOV ${ }^{2}$, \\ Karin VOIGTLÄNDER ${ }^{3}$ \& Willi E.R. XYLANDER ${ }^{4}$ \\ ${ }^{1,3,4}$ Senckenberg Museum of Natural History Görlitz, Am Museum 1, 02826 Görlitz, Germany \\ ${ }^{2}$ Queen Victoria Museum and Art Gallery, 2 Invermay Road, Launceston, Tasmania 7248, Australia \\ ${ }^{*}$ Corresponding author: peter.decker@senckenberg.de \\ ${ }^{2}$ Email: robert.mesibov@gmail.com \\ ${ }^{3}$ Email: karin.voigtlaender@senckenberg.de \\ ${ }^{4}$ Email: willi.xylander@senckenberg.de \\ ${ }^{1}$ urn:1sid:zoobank.org:author:67EAB8FA-C93C-4F50-9F3F-A22735014D6F \\ 2 urn:lsid:zoobank.org:author:24BA85AE-1266-494F-9DE5-EEF3C9815269 \\ ${ }^{3}$ urn:lsid:zoobank.org:author:6F708F5C-12D6-4B64-8B4D-76F821C79C21 \\ ${ }^{4}$ urn:lsid:zoobank.org:author:C2567283-03A8-4B0B-A2C1-C66226416686
}

\begin{abstract}
The southeastern Australian millipede genus Pogonosternum Jeekel, 1965 is revised. Pogonosternum nigrovirgatum (Carl, 1902), P. adrianae Jeekel, 1982 and P. laetificum Jeekel, 1982 are redescribed; $P$. jeekeli Decker, sp. nov. and $P$. montanum Decker, sp. nov. are described from Victoria, New South Wales and Tasmania. P. nigrovirgatum infuscum Jeekel, 1982 and $P$. coniferum Jeekel, 1965 are junior synonyms of $P$. nigrovirgatum (Carl, 1902). An updated key to all five species of the genus is presented.
\end{abstract}

Keywords. Arthropoda, Australia, new species, Bass Strait.

Decker P., Mesibov R., Voigtländer K. \& Xylander W.E.R. 2017. Revision of the Australian millipede genus Pogonosternum Jeekel, 1965, with descriptions of two new species (Diplopoda, Polydesmida, Paradoxosomatidae). European Journal of Taxonomy 259: 1-34. http://dx.doi.org/10.5852/ejt.2017.259

\section{Introduction}

The family Paradoxosomatidae is one of the largest families of millipedes with 198 named genera and at least 975 valid species (Nguyen \& Sierwald 2013). Australia has 40 genera and more than 139 described species of predominantly short range endemics (Mesibov 2006-2016) and hundreds of undescribed paradoxosomatid species in New South Wales (Car 2009), Queensland (Mesibov 2008) and Western Australia (Car et al. 2013). 
Pogonosternum is the dominant genus in the subfamily Australiosomatinae, tribe Antichiropodini in Victoria, which only has two other described Antichiropodini, both in monotypic genera: Dicranogonus pix Jeekel, 1982 and Notodesmus scotius Chamberlin, 1920.

Pogonosternum was erected by Jeekel (1965) for Akamptogonus nigrovirgatus (Carl, 1902), which had been described as Strongylosoma nigrovirgatum from Melbourne, Victoria (Carl 1902) and transferred to Akamptogonus Attems, 1914 by Attems (1914). Pogonosternum coniferum Jeekel, 1965 was then later added (Jeekel 1965), followed by P. adrianae Jeekel, 1982, P. laetificum Jeekel, 1982 and the subspecies P. nigrovirgatum infuscum Jeekel, 1982, together with a key to species (Jeekel 1982a).

Although all Pogonosternum species were described from Victoria, Jeekel (1982a) and Mesibov \& Churchill (2003) both mentioned undescribed Pogonosternum species from Tasmania. Moreover, Car (2010) listed two undescribed Pogonosternum species from New South Wales. The Tasmanian records are of interest because the other two Victorian antichiropodine genera, Notodesmus Chamberlin, 1920 and Dicranogonus Jeekel, 1982, also extend to Tasmania (Mesibov 2014; maps in Mesibov 2006-2016).

Relationships within the genus Pogonosternum were recently investigated, using an integrative approach incorporating sequence data and morphology of gonopods (Decker 2016a). The phylogenetic analysis revealed five species groups, of which two were undescribed: one from the Australian Alps in New South Wales and Victoria, and another with a trans-Bass Strait distribution in northeastern Tasmania and eastern Victoria. The five species groups exhibit a high intraspecific genetic variability and highly localized haplotypes, suggesting that they were confined to multiple refugia during Pleistocene glacial cycles on the southeastern Australian mainland. Furthermore, the data suggest that northwestern Tasmania was colonized by P. nigrovirgatum, probably from central Victoria, and northeastern Tasmania by an as yet undescribed species from eastern Victoria (Decker 2016a).

The present paper reviews the genus Pogonosternum based on extensive new collections and adds two new species from Victoria, New South Wales, and Tasmania. Three species are redescribed, one species and one subspecies are synonymised, and an updated key to all species is provided.

\section{Material and methods}

\section{Specimen collecting and preservation}

Pogonosternum specimens were collected by hand in Victoria and New South Wales in August 2014 by Decker, Voigtländer and Mesibov. Most sites were searched for 1-3 hours with the aim of finding 1-3 adult males; at only a few localities Pogonosternum was abundant. Specimens were killed and stored in $95 \%$ ethanol, with a change of ethanol (95\%) after 1-2 months. Specimens in 70-80\% ethanol were borrowed from the collections of various natural history museums noted in the text. A total of 810 specimens were examined, and locality, date, collector, collection number and coordinates (WGS84 decimal degrees) for all records are provided in Supplement 1.

\section{Illustrations}

Millipedes were photographed alive in the field. Preserved specimens were imaged with a Leica ${ }^{\circledR}$ Z6 Apo stereo microscope and Leica ${ }^{\circledR}$ DFC420 camera. Focus-stacked images were assembled from 25-40 source images using the software package Leica ${ }^{\circledR}$ Application Suite 4.5.

Gonopod drawings were traced from printed photographic images using a light box.

For scanning electron microscopy (SEM), samples were dehydrated through an ethanol series $(80 \%, 90 \%$, $2 \times 99.9 \%$ ), dried in a desiccator overnight, and mounted on aluminium stubs before being sputter coated 
with gold-palladium. SEM images were acquired digitally using a JEOL JSM-6510 LV microscope, and samples were removed from stubs and returned to alcohol after examination.

All images were later edited using Adobe Photoshop CS4 and assembled into plates. The distribution map was created with ArcGIS version 10.

\section{The following abbreviations are used in the text and figures}

$\begin{array}{ll}\mathrm{C} & =\text { coxite } \\ \mathrm{F} & =\text { Femorite } \\ \mathrm{fp} 1 & =\text { femoral process } 1 \\ \mathrm{fp} 2 & =\text { femoral process } 2 \\ \mathrm{lp} & =\text { lateral process } \\ \mathrm{PF} & =\text { prefemorite } \\ \text { prof } & =\text { prolongation of femorite } \\ \mathrm{S} & =\text { solenomere } \\ \text { stp } & =\text { solenomere tip process. }\end{array}$

\section{Institutional abbreviations}

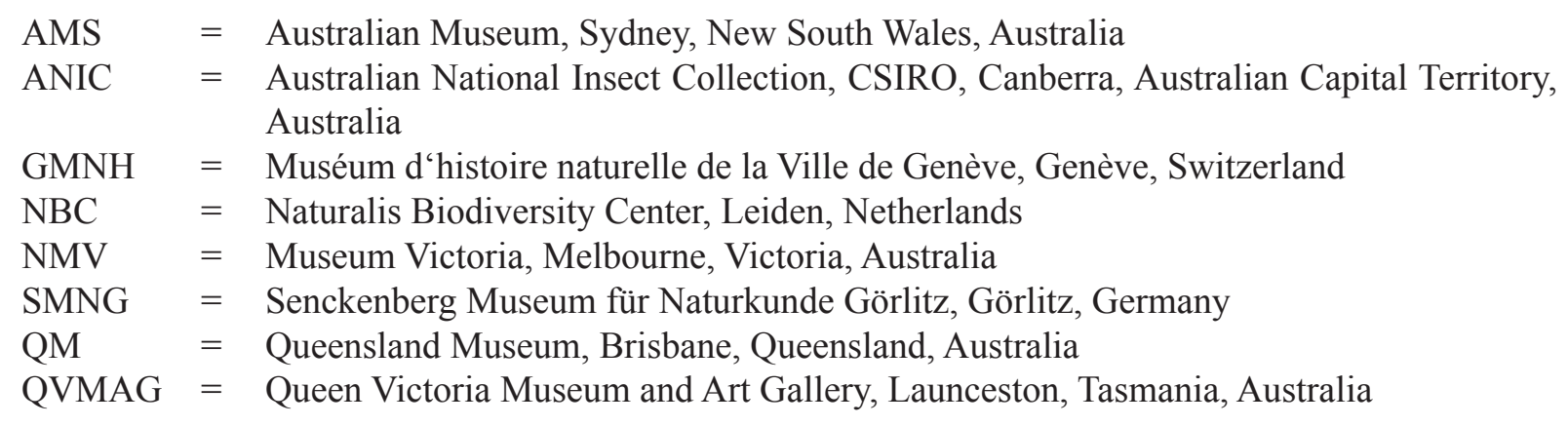

\section{Results}

Order Polydesmida Pocock, 1887

Family Paradoxosomatidae Daday, 1889

Subfamily Australiosomatinae Brölemann, 1916

Tribe Antichiropodini Brölemann, 1916

Genus Pogonosternum Jeekel, 1965

Fig. 1

Type species: Strongylosoma nigrovirgatum Carl, 1902, by original designation.

\section{Diagnosis}

A small to moderate-sized antichiropodine genus (1.5-2.8 cm) with 1-2 broad, yellowish or yellowishwhite longitudinal stripes on dorsum contrasting with more or less dark brown ground; with 20 body rings, each smooth, waist distinct between prozonite and metazonite, pore formula 5, 7, 9, 10, 12, 13, 15-19; paranota poorly developed on anterior rings, absent on posterior rings; small bean-shaped area present behind each antennal socket; male with femoral process (= adenostyle) on legpair 1 and tarsal and tibial brushes from legpair 1 to legpairs 7-12 (variable); ventrolateral hook-like process on anal valves. 
The genus is best defined by the gonopod structure (Fig. 1). All Pogonosternum species have an anterior laminate femoral process $1(f p l)$ with a second adjacent smaller femoral process $2(f p 2)$. A large prolongation of the femorite (prof) bears close to its base a lateral femoral sub-process $(l p)$, slightly distal to the anteriorly arising solenomere $(S)$. The solenomere is long, laminate and nearly semicircular with a single slender solenomere tip process (stp) directed apically.

A similarly curving solenomere is present in the antichiropodinae genera Antichiropus Attems, 1911, Helicopodosoma Verhoeff, 1924 and Notodesmus Chamberlin, 1920, but, apart from Antichiropus, a prolongation of the femorite (prof) is absent or only poorly developed in these genera. Antichiropus species differ in having a longer, nearly circular solenomere with a process on its inner surface one third of the distance to the apex and often additional solenomere processes.

In the field, Pogonosternum species are easily distinguished from other paradoxosomatid species in southeastern Australia by their distinctive colour pattern and lack of midbody paranota.

\section{Description}

The members of the genus Pogonosternum are very homogeneous in their morphology, although some non-gonopod characters can be used in combination with gonopod features to distinguish species: body length, colouration, distribution of male leg brushes, coxal processes on second legpair of females and form of anterior spiracles.

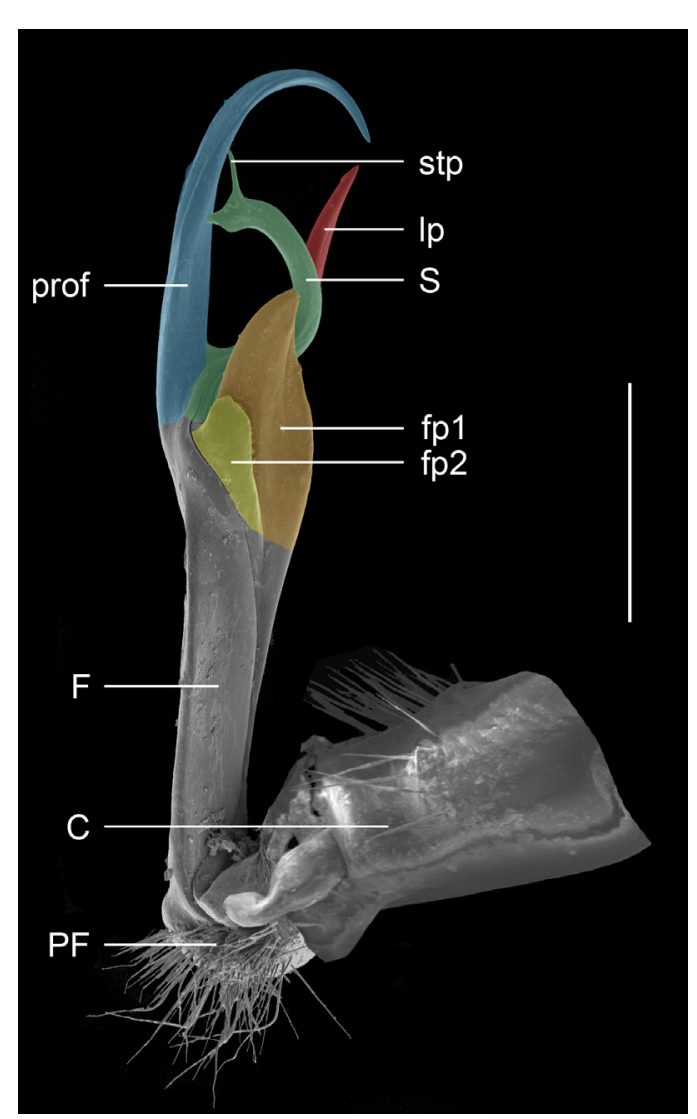

Fig. 1. Right gonopod of Pogonosternum nigrovirgatum (Carl, 1902), mesal view (NMV K-12158). Scale bar: $0.5 \mathrm{~mm}$.
The following general description applies to all species if not otherwise mentioned in the text or descriptions of species.

Colouration. Colour in fresh material (Figs 8, 12, 15, 18, 22, 26): head blackish brown, lateral side, labrum and behind antennal sockets chestnut brown. Antennae blackish brown; distal margins of antennomeres, basal antennomere and base of setae lighter. Legs chestnut brown, tarsus darker. Collum blackish brown with median brownish-yellowish goblet-shaped stripe narrowing in anterior $1 / 3$ of length from anterior margin. Dorsum with one or two contrasting light yellowish brown, broad, longitudinal stripes reaching from collum to epiproct. Flanks and area around ozopores more or less lighter. Anal ring blackish brown with light yellowish brown median stripe, epiproct entirely light brown to pale. Colour stripe sometimes absent from anal ring and only epiproct lighter. Margin of anal ring and anal valves lighter. Hypoproct pale.

Gonopod MORPhOLOGY. Parts of the telopodite are named following Car et al. (2013), with differing terms used by Jeekel $(1965,1982 a)$ given in brackets (Fig. 1). Coxite = $C$; femorite $=F$; femoral process $=f p l$ (femoral process, process $\mathrm{f}$ ), $f p 2$ (lobe at transition between femur and postfemur, process a); lateral process $=l p$ (postfemoral process, process c); prefemorite $=P F$; prolongation of femorite $=$ prof $($ tibiotarsus, process b); solenomere $=S$ (process k); solenomere tip process $=s t p$. 

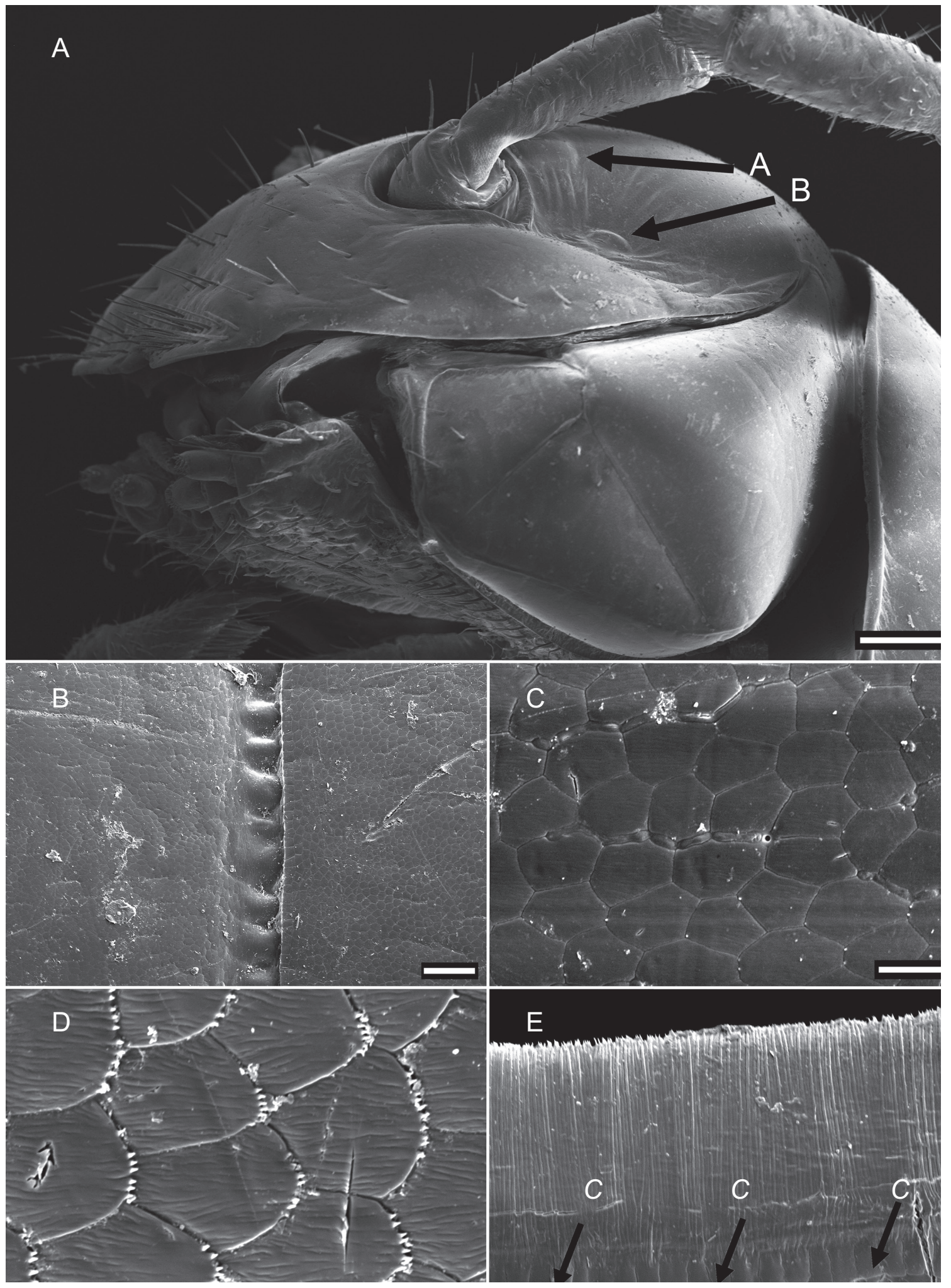

Fig. 2. A. Head, left lateral view Pogonosternum montanum Decker, sp. nov. (AMS KS106884). B-E. Midbody ring structure of P. nigrovirgatum (Carl, 1902) (NMV K-12158). B. Suture between prozonite (right) and metazonite (left). C. Metatergite surface with micro-scales and pores. D. Ventral metazonite surface. E. Limbus, dorsal view. Abbreviations: $A=$ beanshaped area; $B=$ lateral circular area; $C=$ micro-pores. Scale bars: $\mathrm{A}=0.2 \mathrm{~mm}, \mathrm{~B}=50 \mu \mathrm{m}, \mathrm{C}-\mathrm{E}=10 \mu \mathrm{m}$. 
Femorite $(F)$ moderately long, moderately slender or slightly enlarged distally. Femoral process $1(f p l)$ arising from anterior apical part of translucent fringe of femorite, in most species developed as moderate to large subtriangular process. Femoral process $2(f p 2)$ arising mesad-posteriad to femoral process 1 $(f p l)$ and, except in $P$. adrianae, often much smaller than $f p 1$ or greatly reduced, as in P. laetificum. Long prolongation of femorite (prof) arising posteriorly. Above base of prof a slender lateral process ( $l p)$, except in P. montanum Decker, sp. nov. where it is on mesal side and arises distal to the solenomere. Semicircular solenomere $(S)$ arising anteromesally above $l p$, with a single slender solenomere tip process $(s t p)$.
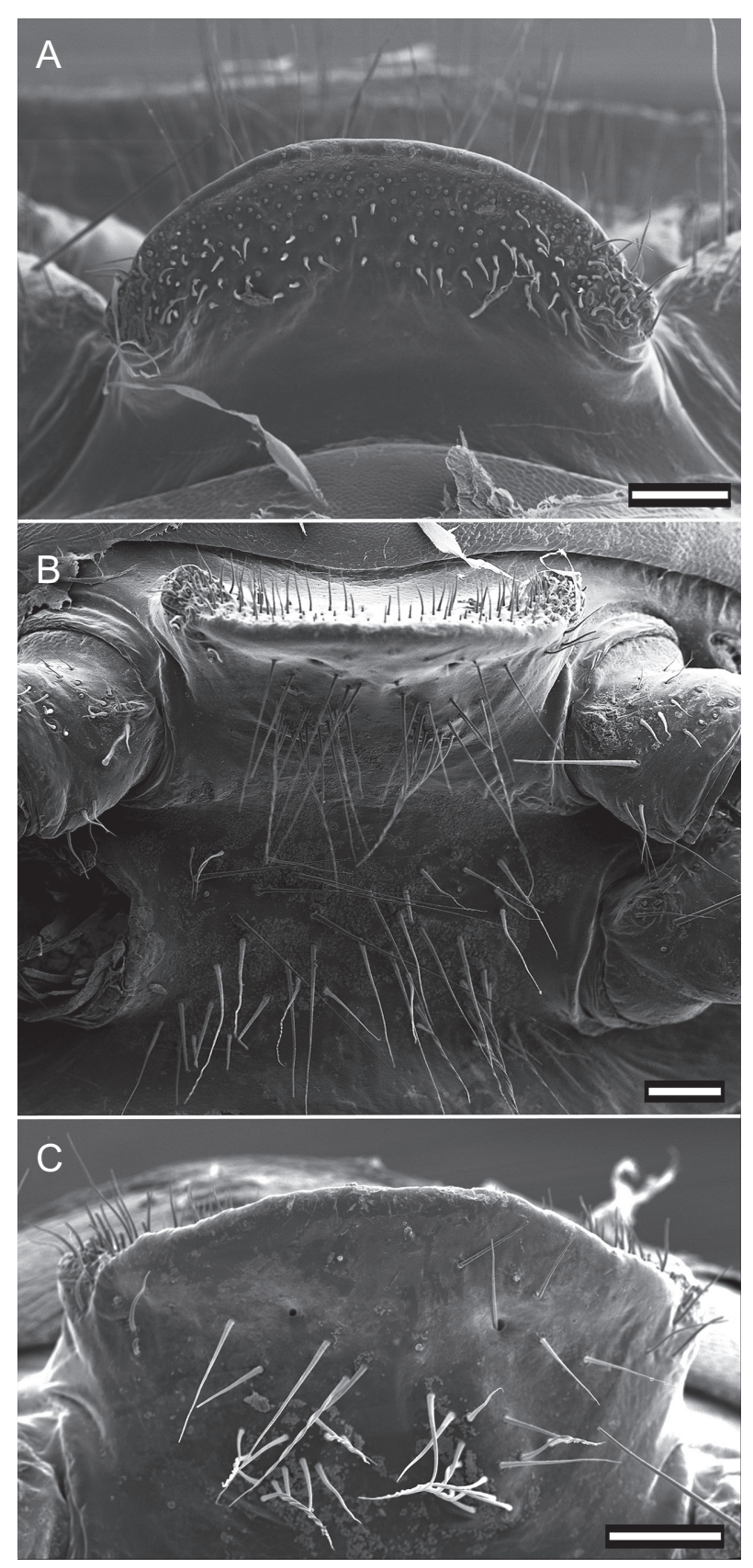

Fig. 3. Male sternite lamella on ring 5 of Pogonosternum nigrovirgatum (Carl, 1902) (NMV K-12158). A. Anterior view. B. Ventral view. C. Posterior view. Scale bars: $0.1 \mathrm{~mm}$.
The solenomere with its $s t p$ is the only nonvarying feature of the telopodite in the known species of Pogonosternum. While intraspecific morphological variability of gonopods in P. adrianae and P. montanum Decker, sp. nov. is low, various local forms and intermediate states of gonopod characters have been found in $P$. nigrovirgatum, $P$. laetificum and $P$. jeekeli Decker, sp. nov. As shown by Decker (2016a), the distribution of these variations does not correlate clearly with geographical distribution or phylogenetics.

Head. Slightly broader than collum. Frons and vertex sparsely setose, clypeus moderately setose, more dense on labrum. Vertigial sulcus well-defined, starting slightly above level of antennal sockets. Postantennal grove moderately wide and deep, the wall in front not conspicuously prominent. Antenna reaching dorsally when stretched to ring 3. Antennomeres slender, nonclavate, antennomeres 2-6 with equal lengths. Antennomere pubescence moderately dense, denser and longer distally. A slightly swollen and lighter circular area, called the bean-shaped area by Jeekel (1982a), behind antennal sockets and a slightly swollen and lighter circular area in a depression within the postantennal groove (Fig. 2A). The two structures may represent sense organs such as the Tömösváry organ or intracerebral photoreceptors (=accessory lateral eyes), which have not yet been studied in Polydesmida (see Müller \& Sombke 2015).

BoDy RINGS. Adults with 20 body rings, each smooth. In width, head $<$ collum $>$ ring $2>$ $3>4=5<6-16$; thereafter body gradually tapering. Collum in dorsal view with anterior margin nearly straight and posterior margin scarcely emarginated; laterally rounded with distinct emargination and a short anterolateral shallow dent. Diplosegments with pronounced 
waist, suture moderately deep and strongly corrugated (Fig. 2B). Slightly irregular longitudinal striation sometimes present ventrolaterally. Metatergite with smooth and transverse sulcus from $5^{\text {th }}$ to $17^{\text {th }}$ ring, hardly traceable in last two rings. No setae present on metatergites. Paranota only present on rings 2 and 3, sometimes also on ring 4, as ridge with dorsal furrow caudally curving upwards, on subsequent rings only indicated by irregular striation. In females, pleurites of ring 2 with small lobiform toothed lappet directed caudally. Opening of ozopores on lateral side of metazonite at about two-thirds of metazonite length, each lying inside a shallow round pit. Area around ozopores only very slightly swollen; pore formula 5, 7, 9, 10,12,13,15-19. Prozonite and metazonite surface with smooth cellular structure at higher magnification. Micro-scales and pores (= micro-scutes, Akkari \& Enghoff 2011)

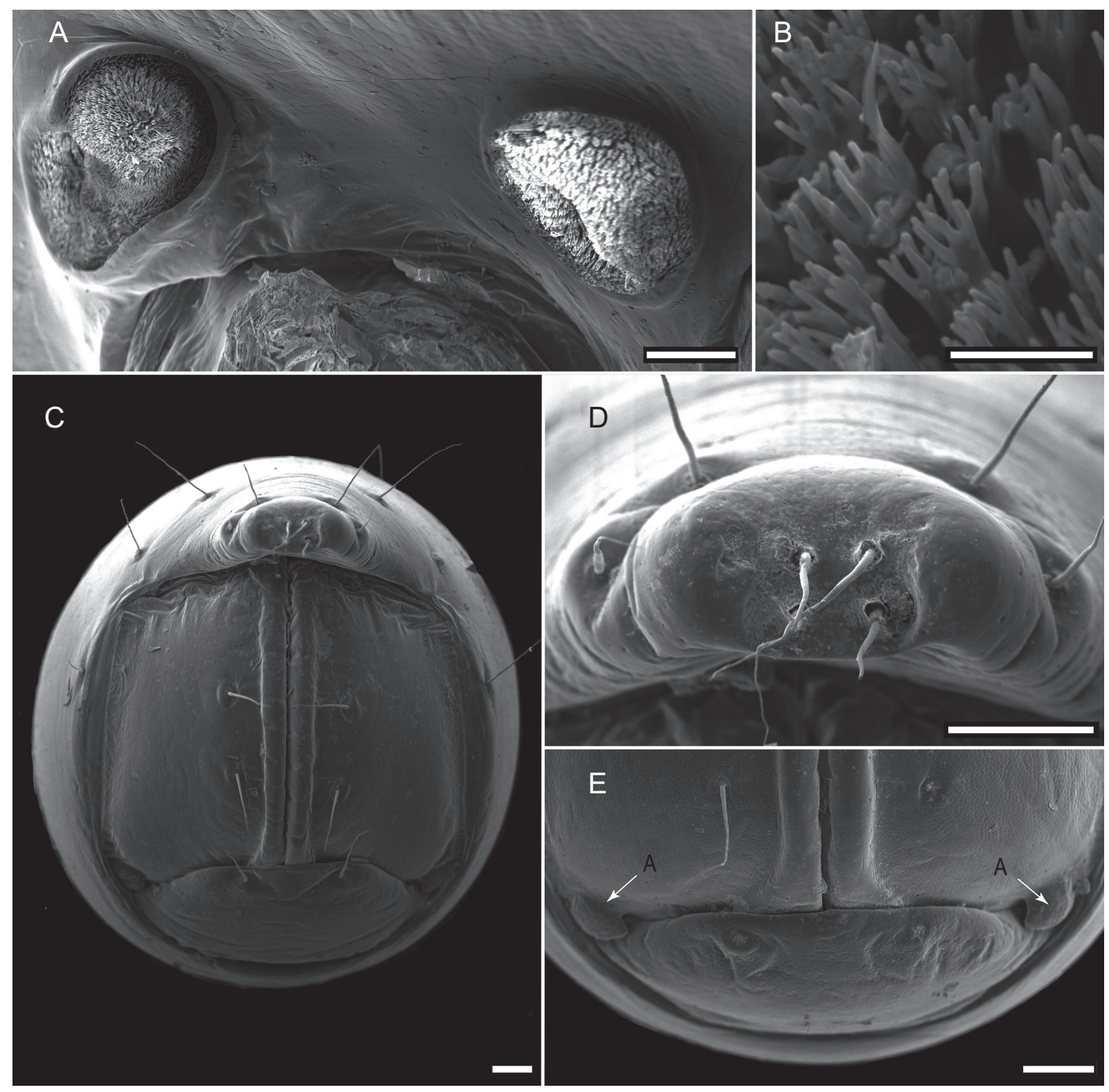

Fig. 4. Pogonosternum montanum Decker, sp. nov. A-B. Spiracles on left midbody ring, lateral view (AMS KS 106884). A. Overview of anterior (left) and posterior (right) spiracles. B. Spiracular filter of anterior spiracle. C-E. Telson, posterior view (NMV KS106884). C. Telson overview. D. Spinnerets. E. Anal valves and hypoproct. Abbreviations: $A=$ ventrolateral hook-like process. Scale bars: $\mathrm{A}=$ $50 \mu \mathrm{m}, \mathrm{B}=5 \mu \mathrm{m}, \mathrm{C}, \mathrm{D}, \mathrm{E}=0.1 \mathrm{~mm}$. 
present on metazonites, especially on metatergites and towards posterior margin (Fig. 2C), ventrally cells with dentation (Fig. 2D). Limbus long, lamellar with microdentate fringe arising from a row of subrectangular cells. Single cells of second cell row anterior to limbus anterolaterally with two micropores, between these cells, 3-6 cells without micro-pores (Fig. 2E).

Sternites a little wider than long, transverse depressions deeper than longitudinal, moderate and long setation, directed mostly posteroventrally. Rounded-trapezoidal lamella between anterior legpair on ring 5 (Fig. 3). No significant variation of shape of lamella was observed within or between species. Small to prominent cones near base of anterior and midbody legs pointing ventrad are only present within local populations of $P$. nigrovirgatum.

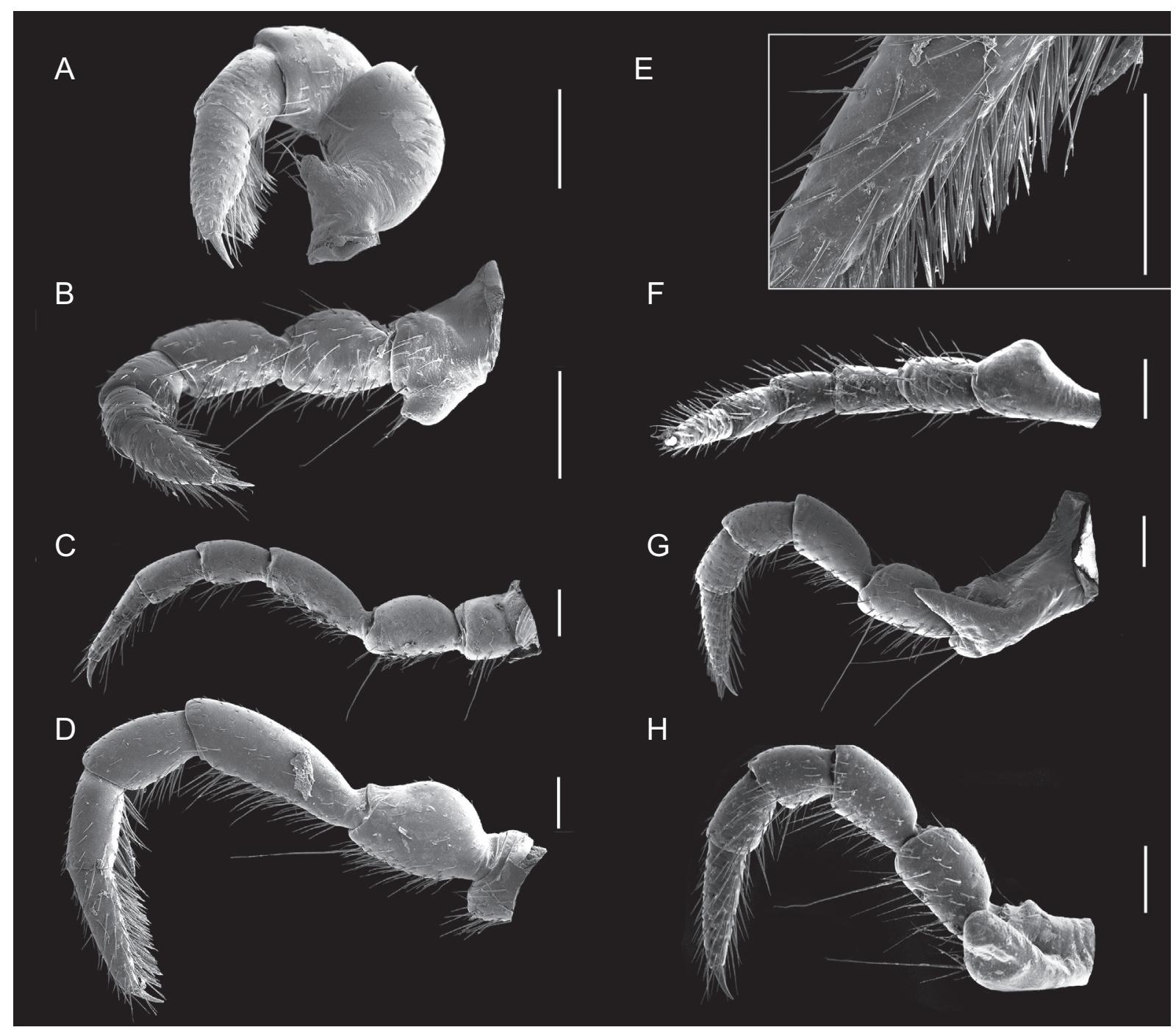

Fig. 5. Legs of Pogonosternum. A, D-E. P. nigrovirgatum (Carl, 1902) (NMV K-12158). A. Male left leg 1, posterior view. B. P. nigrovirgatum (Carl, 1902) (QVMAG 23:46359), male right leg 2, anteroventral view. C. P.jeekeli Decker, sp. nov. (AMS KS106742), male midbody leg, anterior view. D. Male right leg 7 , anterior view. E. Male tarsus of right legpair 7, anterior view. F. P. laetificum Jeeker, 1982 (NMV K-9957), female left leg 2, ventral view. G. P. adrianae Jeeker, 1982 (NMV K-12203), female left leg 2, anterior view. H. P. montanum Decker, sp. nov. (AMS KS106907), female left leg 2, anterior view. Scale bars: $0.2 \mathrm{~mm}$. 
SPIRACLES. Well-separated on diplosegments (Fig. 4A). Anterior spiracle located anterodorsally of anterior leg coxa, posterior spiracle located relatively more anteriorly above posterior leg. Spiracular rim a more or less raised wall. Spiracular opening filled with spiracular filter composed of numerous distally bifurcated lamellae (Fig. 4B); filter can be U-folded or twisted, emergent above rim or not. Anterior spiracles ovoid, rim raised and often with an anterodorsal extension. Posterior spiracle ovoid to subtriangular, rim low without conspicuous extensions.

Telson. With two dorsolateral setae and one lateral seta in one line on each side with slightly produced papillae (Fig. 4C). Epiproct with tip truncate, slightly curving downwards, lateral and dorsal setal papillae moderately produced. Spinnerets located in smooth depression, arranged in trapezoid with dorsal setae slightly closer together than ventral. A more or less distinct rounded notch located lateral to ventral row of spinnerets. Individual spinneret seta with short single-walled sleeve (Fig. 4D). Anal valves each with two long setae and raised margin, with broad uncinate process on lateroventral portion of anal valves. Hypoproct subtrapezoidal with two long setae and slight depression on laterodorsal portion (Fig. 4E).

LEGS. Of moderate length extending laterally and easily visible from above. All species of Pogonosternum have similarly shaped legs. Male legpair 1 with well-developed ventral adenostyle on femur (Fig. 5A). Coxa of legpair 2 with posteroventrally directed conical process bearing laterally a set of setae and the gonopore opening at tip of process (Fig. 5B).

Dense setal pads or brushes on tarsus and tibia of males present from legpair 1 to legpair 7-12 (Fig. 5D-E), thereafter gradually thinning out or abruptly absent. Posterior-most walking legs without dense brushes (Fig. 5C).

In female, legs are slightly shorter than in male. Coxa of legpair 2 with prominent swelling on posterior side (Fig. 5F) especially, distinct processes in $P$. montanum sp. nov. and P. adrianae (Fig. 5G-H).

VuLva. Subtriangular, widest posteriorly (Fig. 6). Numerous setae on inner and outer valves, longest ventrally and posteriorly. Operculum with 3-4 long and 2-3 small setae on each side ventrally. Above 9-12 moderate long setae. No significant interspecific differences were observed, and both shorter and longer setae on valves can occur within a species.

\section{Distribution}

On the Australian mainland, the genus Pogonosternum has its main distribution area in eastern, northeastern and central Victoria and southeastern New South Wales (Fig. 7).

Pogonosternum has not yet been found in far Eastern Gippsland or west of the Otway Ranges and the Ballarat area. Like the paradoxosomatid species Dicranogonus pix Jeekel, 1982 and

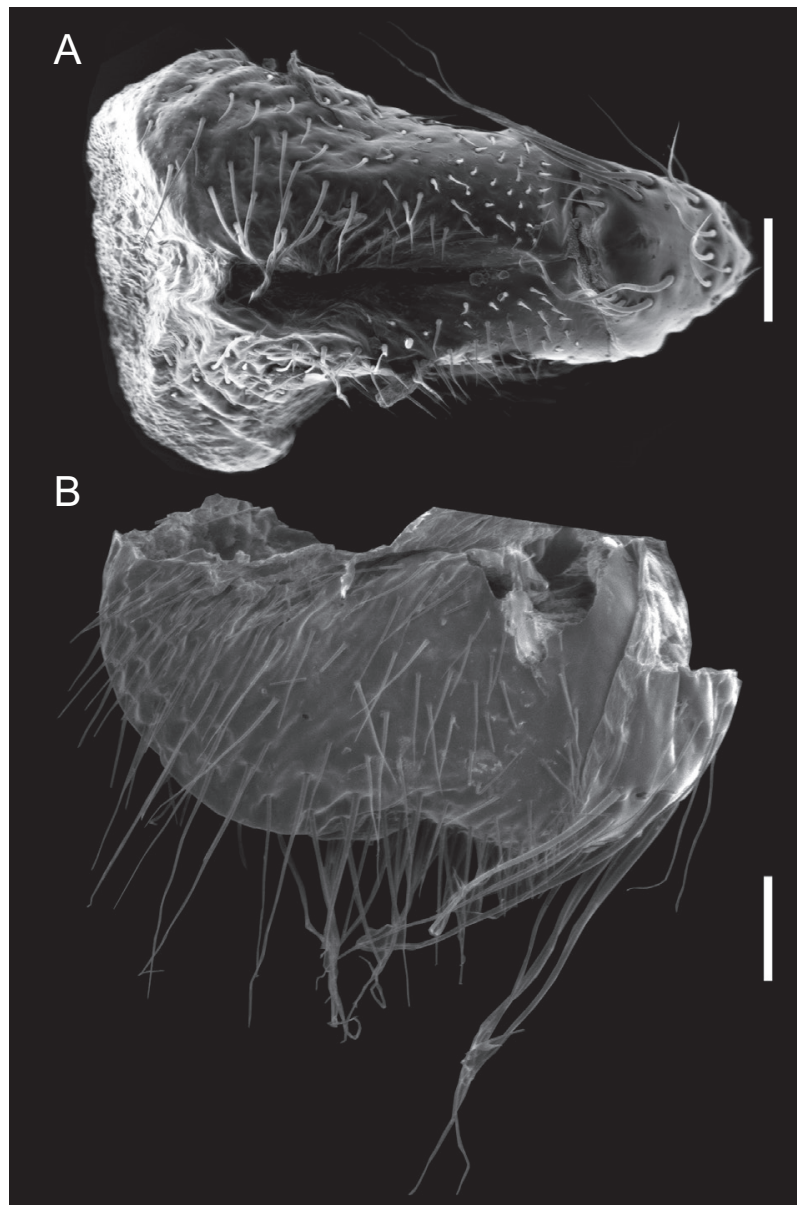

Fig. 6. A. Pogonosternum laetificum Jeekel, 1982 (NMV K-12203), right vulva, ventral view. B. P. nigrovirgatum (Carl, 1902) (NMV K-13356), right vulva, lateral view. Scale bars: $0.1 \mathrm{~mm}$. 
Notodesmus scotius Chamberlin, 1920 (Mesibov 2014), Pogonosternum nigrovirgatum and P. jeekeli sp. nov. have ranges extending from Victoria through the Bass Strait Islands to the Tasmanian mainland. None of the known Pogonosternum species can be regarded as a short-range endemic.

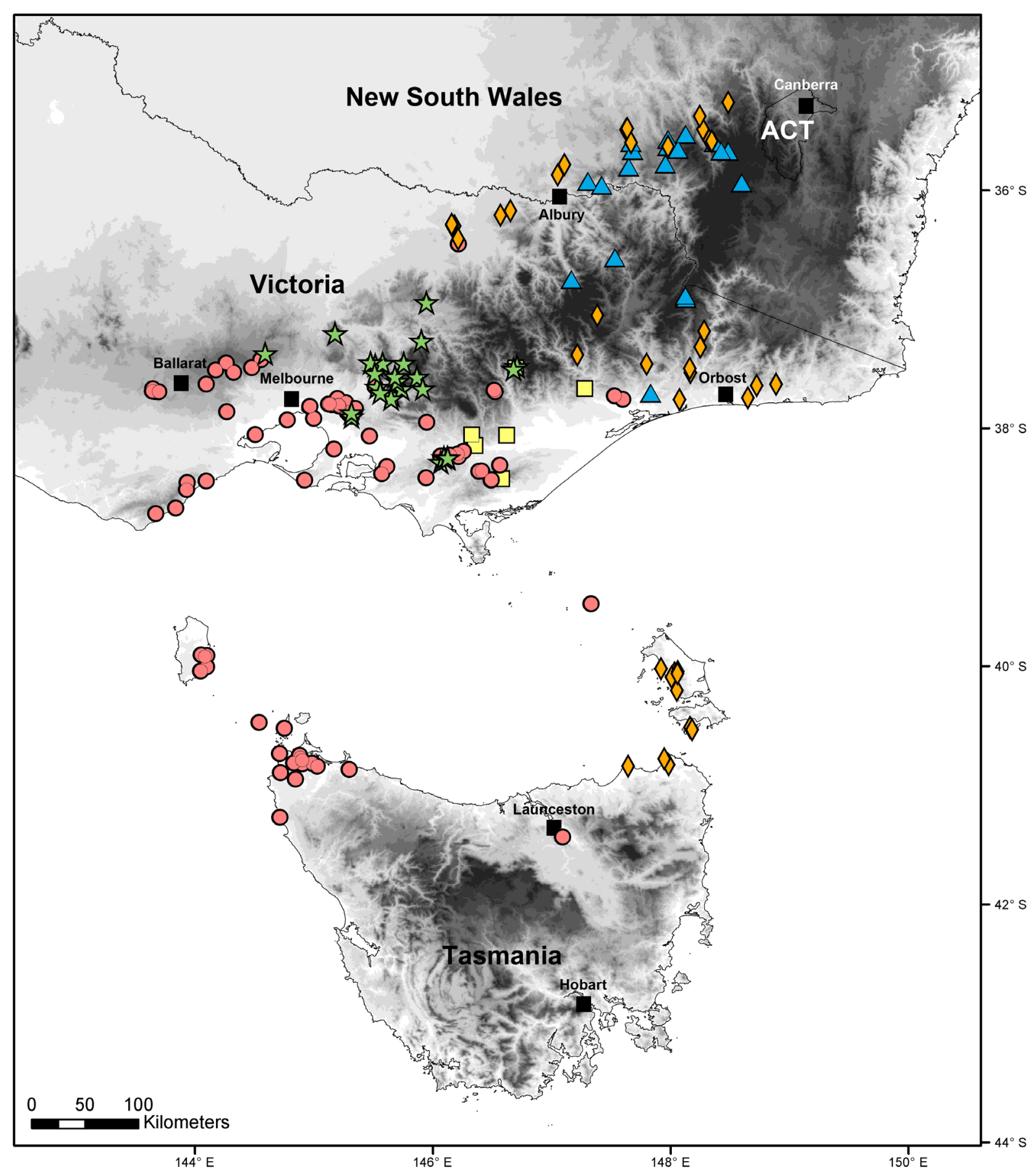

Fig. 7. Map of southeastern Australia and Tasmania, showing the known distribution of Pogonosternum spp.: red circles $=$ P. nigrovirgatum $($ Carl, 1902); green stars $=$ P. laetificum Jeeker, 1982; yellow squares $=$ $P$. adrianae Jeeker, 1982; blue triangles $=P$. montanum Decker, sp. nov.; orange diamonds $=P$. jeekeli Decker, sp. nov. Abbreviation: ACT $=$ Australian Capital Territory. 


\section{Notes on ecology and biology}

Adults and juveniles (mostly subadults) of Pogonosternum are present on the surface in the cold or cool and rainy winter months, with a mating and activity peak between July and September. The genus can be found from near sea level (P. nigrovirgatum, P. jeekeli sp. nov.) to $1110 \mathrm{~m}$ a.s.l. (P. montanum sp. nov. in Kosciuszko National Park) and mostly inhabits forests, but $P$. jeekeli Decker, sp. nov. can also be found in coastal heathland in northeastern Tasmania (Mesibov \& Churchill 2003), whereas P. jeekeli sp. nov. and P. montanum sp. nov. also occur in pine plantations (Car 2010). Pogonosternum species were preferably recorded from moist, but not wet, leaf litter. In some cases, specimens were found under loose bark on the forest floor and in a few cases, adult males were observed walking during the daytime on gravel roads.

\section{Relationships}

According to Jeekel (1982a) the Western Australian genus Antichiropus Attems, 1911 or the Queensland genus Aulacoporus Verhoeff, 1924 is the nearest relative. Humphreys \& Shear (1993) mentioned Pogonosternum as related to Antichiropus and Stygiochiropus Humphreys \& Shear 1993. Jeekel (2006) suggested Howeosoma Jeekel, 2006 from Lord Howe Island as the nearest relative of Pogonosternum.

However, the gonopods of Pogonosternum are unique within Antichiropodini, and its relationships within Antichiropodini are unclear due to our lack of understanding of the homology of the different processes of the gonopod. Jeekel (1987: 11) even questioned the division of Australian Australiosomatinae into two tribes: "Although these two groups are maintained here, it must be emphasized that this division probably gives an oversimplified picture of the actual systematic relationship between the genera involved. With the recent discovery of more taxa, it becomes more and more obvious that the classification of the Australian Paradoxosomatidae is more complicated than formerly understood and needs a critical revision". Future integrative phylogenetic studies covering the described and the many undescribed genera will increase our knowledge of relationships and the importance of gonopod characters.

Pogonosternum nigrovirgatum (Carl, 1902)

Figs 1, 2B-E, 3, 5A-B, D-E, 6B, 7-11, 26A

Strongylosoma nigrovirgatum Carl 1902: 567, figs 1, 2.

Pogonosternum nigrovirgatum infuscum Jeekel 1982a: 203, 207; fig. 3; syn. nov.

Pogonosternum coniferum Jeekel 1965: 13, figs 2, 7; syn. nov.

Strongylosoma nigrovirgatum - Brölemann 1916: 539 (mention). — Chamberlin 1920: 120 (record). — Shelley et al. 2000: 97 (record).

Akamptogonus nigrovirgatus - Attems 1914: 222 (key, new combination), 223 (record). - Attems 1937: 253-254 (key, redescription), fig. 316. — Jeekel 1968: 18 (record). — Rowe \& Sierwald 2006: 533 (mention).

Pogonosternum nigrovirgatum - Jeekel 1965: 9 (redescription, new combination), figs 1, 3-6. — Jeekel 1968: 30 (mention). — Jeekel 1981: 51 (record). — Jeekel 1982a: 202-207 (mention, key). — Decker 2016a: 16-27 (record, mention).

Pogonosternum nigrovirgatum nigrovirgatum - Mesibov 2004: 42 (record). — Nguyen \& Sierwald 2013: 1158 (record).

Pogonosternum nigrovirgatum infuscum - Mesibov 2004: 42 (record). — Nguyen \& Sierwald 2013: 1158 (record).

Pogonosternum coniferum - Jeekel 1968: 20-30 (record, mention). — Jeekel 1981: 51 (record). Jeekel 1982a: 202-208 (mention, key). — Mesibov 2004: 42 (record). — Nguyen \& Sierwald 2013: 1158 (record). — Decker 2016a: 16-25 (record, mention). 


\section{Diagnosis}

Differs from the other Pogonosternum species in having two lighter paramedian stripes and a median darker stripe; from $P$. jeekeli Decker, sp. nov., primarily by lateral process $(l p)$ often shorter, not reaching or projecting most distad position of prolongation of femorite (prof), male tarsal and tibial brushes present to legpair 7, sometimes present to legpair 9, but then prof distinctly elongated and broadly curved.

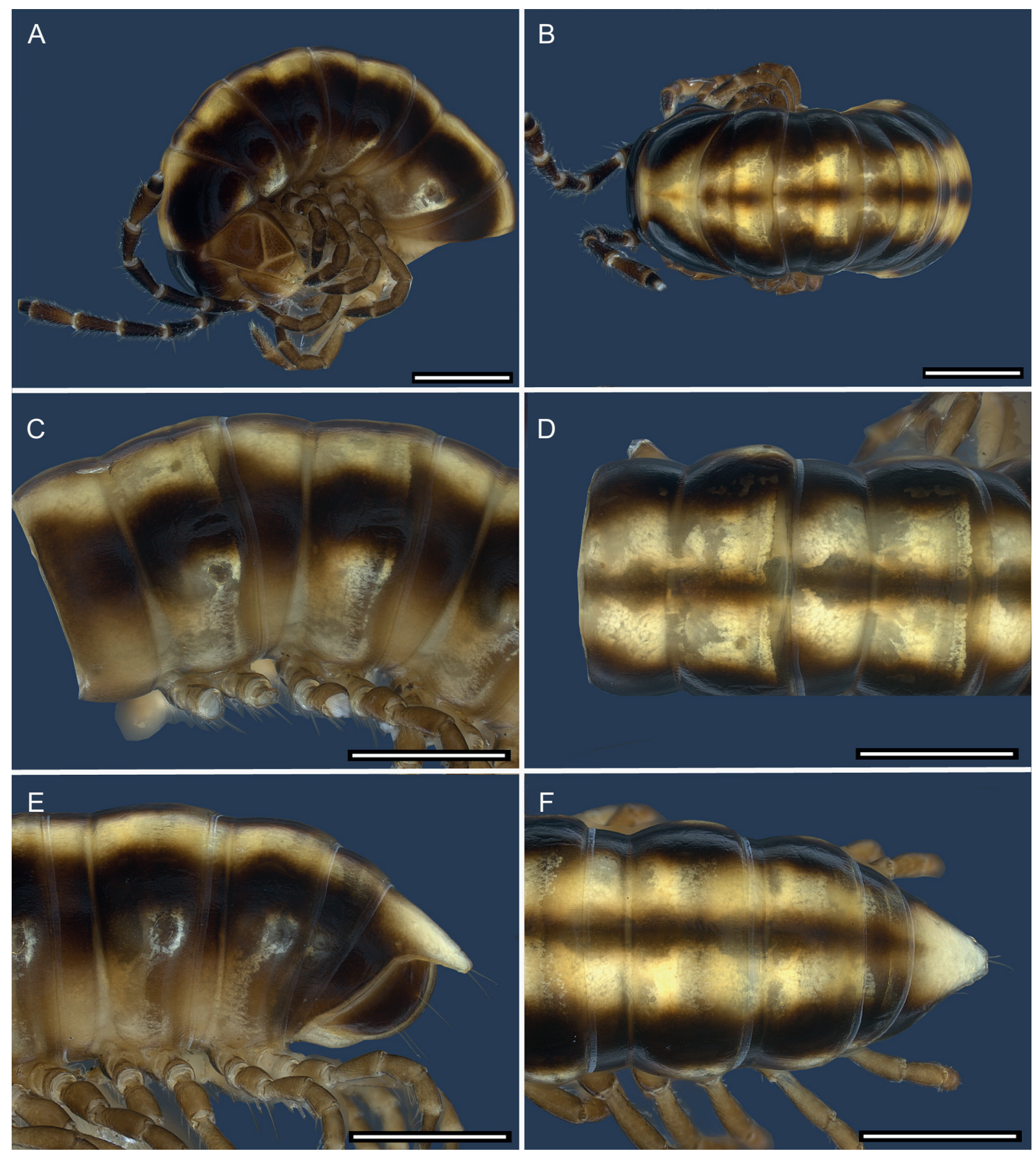

Fig. 8. Pogonosternum nigrovirgatum (Carl, 1902), đ̂, from Kennett River, Grey River Road (NMV K-13114). A-B. Anterior rings. A. Left lateral view. B. Dorsal view. C-D. Rings 10 and 11. C. Left lateral view. D. Dorsal view. E-F. Posterior rings. E. Left lateral view. F. Dorsal view. Scale bars: $1 \mathrm{~mm}$. 


\section{Material studied}

Lectotype (here designated)

AUSTRALIA: 1 ○ Strongylosoma nigrovirgatum, Victoria, Melbourne, leg. Konsul Martin (GMNH).

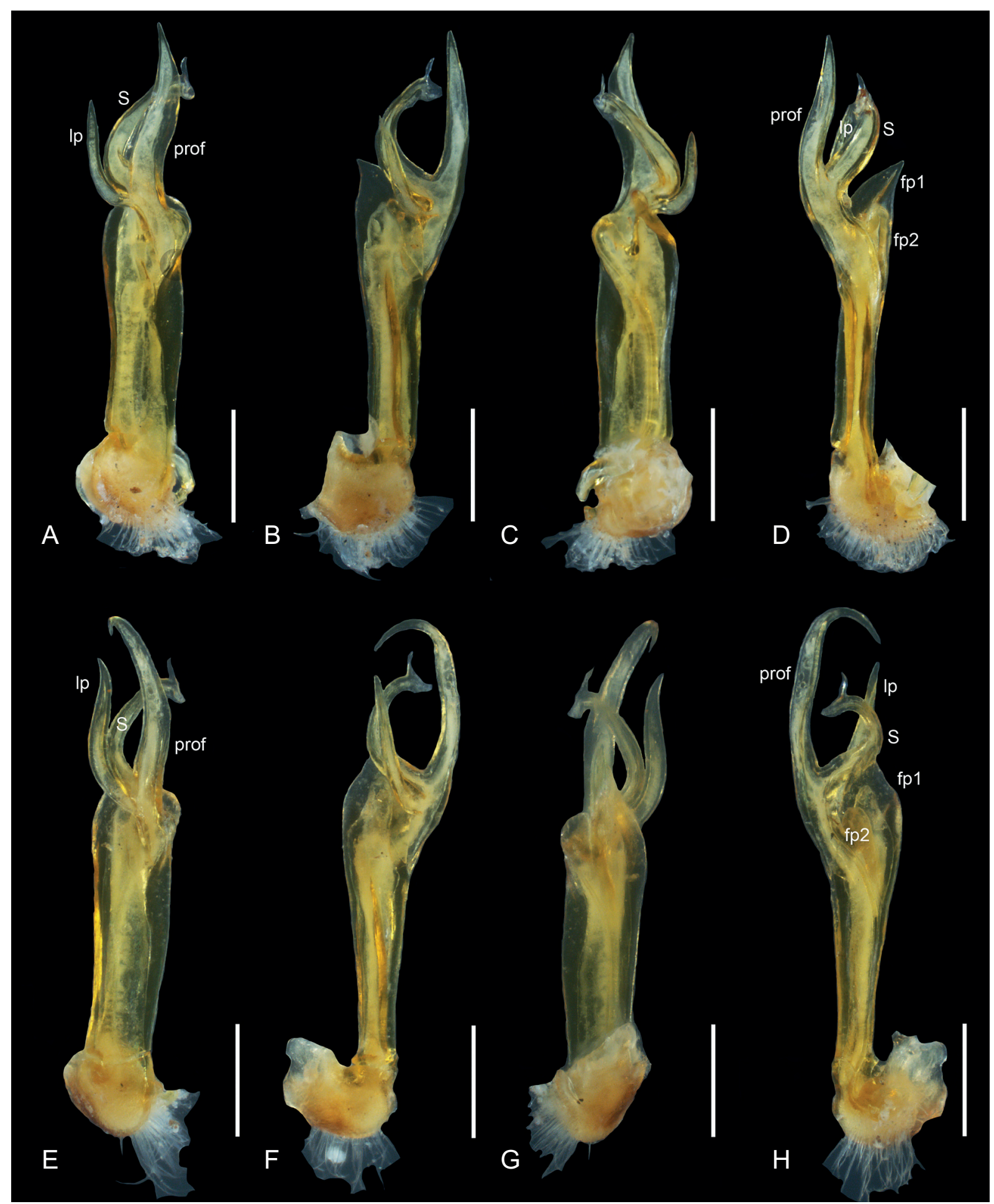

Fig. 9. Pogonosternum nigrovirgatum (Carl, 1902), đ̂, right gonopod. A-D. AMS KS96017 Ferntree Gully. E-H. NMV K-10248 from Sandringham and Brighton. A, E. Posterior view. B, F. Lateral view. C, G. Anterior view. D, H. Mesal view. Scale bars: $0.5 \mathrm{~mm}$. 
Paralectotype (here designated)

AUSTRALIA: 1 + Strongylosoma nigrovirgatum, same data as lectotype (GMNH).

\section{Other material examined}

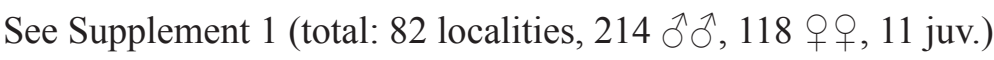

\section{Description}

MeAsuREMENTs. Length ca 1.7-2.4 cm; midbody width ca 1.7-2.2 mm.

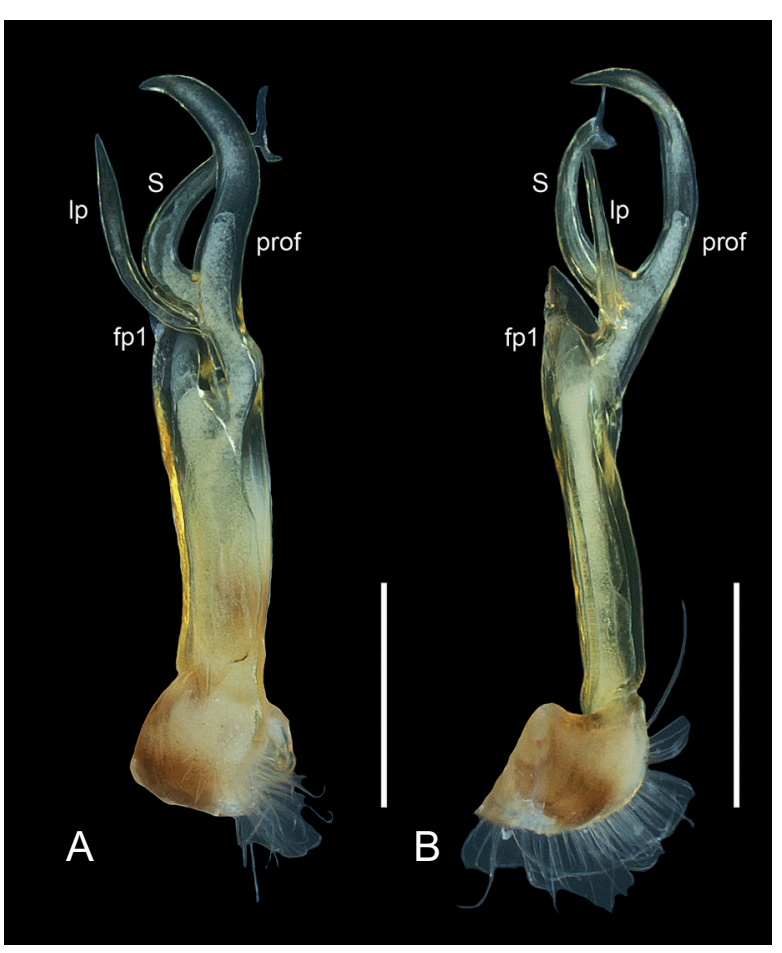

Fig. 10. Pogonosternum nigrovirgatum (Carl, 1902), male, right gonopod (QM 23:40346). A. Posterior view. B. Lateral view. Scale bars: $0.5 \mathrm{~mm}$.

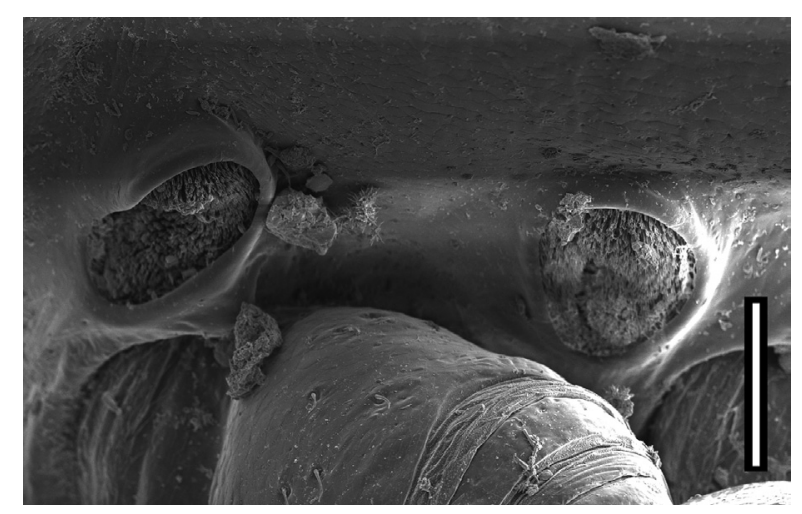

Fig. 11. Pogonosternum nigrovirgatum (Carl, 1902), male, spiracles, midbody ring, left lateral view (NMV K-12158). Scale bar: $0.1 \mathrm{~mm}$.
Colouration. Colour in fresh material (Figs 8, 26A): margin of lateral edges of collum often slightly to distinctly lighter (Fig. 8B). Dorsum with 2 paramedian light yellowish brown stripes and darker median brown stripe. On prozonites the trapezoidal paramedian light band slightly broader anteriorly, and on metazonites slightly broader posteriorly, broadest at $1 / 3$ of length (Figs 8D, 26A). Median darker stripe narrow to rhombic, broadest $3 / 4$ of length on metazonites and prozonites. Flanks often distinctly lighter. Area around ozopores slightly to distinctly lighter, cloudy pale (Fig. 8C).

STERnites. Sometimes with slightly developed sternal cones, especially in anterior and midbody rings.

Legs. Male tarsal and tibial brushes present from legpair 1 to 7 or 9, rarely to 8 . Male coxa of legpair 6 and 7 slightly swollen to cone-like. Female coxa of legpair 2 rarely with slightly enlarged rounded process on caudal side directing posterodistad.

GoNOPODS. Considerable variability present (Figs 1, 9-10). Femorite $(F)$ moderately long and wide. Prolongation of femorite (prof) long to very long, S-shaped. Apical part of prof ranging from short, directed straight distad (Fig. 9A-D), to long, curving posterolaterally, nearly reaching tip of lateral process ( $l p$ ) (Fig. 9E-H). Femoral process 1 ( $f p 1)$ laminate, short, more or less broadly subtriangular with pointed tip, often slightly curved posteriad, not reaching $l p$ and solenomere $(S)$. Femoral process 2 ( $f p 2)$ small, knob-like to subtriangular. Lateral process $(l p)$ on lateral side of prof, short to long, slender, directed distolaterally, sometimes projecting distad of solenomere.

SPIRACles. Anterior spiracles distinctly obliquely ovoid. Rim raised with anterodorsal side often 
broadly extended, not lobiform and spiracular filter not or slightly protruding. Posterior spiracle ovoid with low rim, spiracular filter not protruding (Fig. 11).

\section{Distribution}

From Central Gippsland and central Victoria to the Otway Ranges and Ballarat area; also present in northwestern Tasmania and on King Island (Fig. 7). It has recently been found in the city of Launceston in north central Tasmania, and is apparently introduced there (with short prof).

\section{Remarks}

Carl (1902) described Strongylosoma nigrovirgatum based on one male and one female in the Muséum d'histoire naturelle de la Ville de Genève. The male right gonopod is missing. We designate the male as lectotype and female as paralectotype.

The subspecies P. nigrovirgatum infuscum, described from Central Gippsland, only differs by a broader $f p 1$ from the nominate species. In the material studied here, including material from the type locality of $P$. nigrovirgatum, the width of the $f p l$ differed within some populations from slender to broadly infuscum-like. Pogonosternum n. infuscum is treated here as a synonym of P. nigrovirgatum.

Specimens fitting the description of $P$. coniferum by Jeekel (1965) are restricted to the coastal area around Port Philip Bay. These have a very long and curved prof, a moderate to long $l p$, and male tarsal and tibial brushes present from legpair 1 to 9 (Fig. 9E-H), while in P. nigrovirgatum sensu stricto, distributed from northern central Victoria to Gippsland, prof and $l p$ are short and tarsal and tibial brushes are present to legpair 7 (Fig. 9A-D). However, the Tasmanian, Otway Ranges and western central Victorian populations contain long coniferum-like (Fig. 9E-H) to intermediate states of prof (Fig. 10), sometimes both forms present within one population, with male brushes ranging to legpair 7, except in Brisbane Ranges National Park to legpair 9. Pogonosternum coniferum is here made a synonym of $P$. nigrovirgatum due to the existence of these intermediate forms and the fact that $P$. coniferum clusters with $P$. nigrovirgatum in a phylogenetic analysis based on mitochondrial COI and $16 \mathrm{~S}$ rDNA sequences (Decker 2016a).

The mention of Pogonosternum in northwestern Tasmania by Jeekel (1982a: 202) probably refers to P. nigrovirgatum, although Jeekel does not state what material he examined.

Pogonosternum adrianae Jeekel, 1982

Figs $5 \mathrm{G}, 7,12-14,26 \mathrm{~B}$

Pogonosternum adrianae Jeekel 1982a: 203, 205, fig. 2

Pogonosternum adrianae - Mesibov 2004: 42 (record). — Jeekel 2006: 66 (mention). — Nguyen \& Sierwald 2013: 1158 (record). — Decker 2016a: 16-25 (record, mention).

\section{Diagnosis}

Differs from other Pogonosternum species in having one lighter longitudinal stripe and no median darker stripe; from $P$. montanum Decker, sp. nov. and P. laetificum primarly by the enlarged femoral process 1 $(f p 1)$ and $2(f p 2)$ and the lateral process ( $l p)$ directed laterally, but also by the presence of a subtriangular pointed process of the female leg 2 coxa; male tarsal and tibial brushes present from legpair 1 to 7 ; anterior spiracles obliquely ovoid with anterodorsally slightly extended rim and spiracular filter not protruding; largest known species of Pogonosternum with midbody width of 2.8-3.2 mm. 


\section{Material studied}

\section{Holotype}

AUSTRALIA: 1 , Victoria, Toongabbie, $18 \mathrm{~km}$ NNE of Traralgon, margin of Eucalyptus forest with grassland, under logs, 15 Nov. 1980, leg. C.A.W. Jeekel and A.M. Jeekel-Rijvers (NBC).

\section{Paratypes}

AUSTRALIA: 1 §, same data as holotype (NBC).
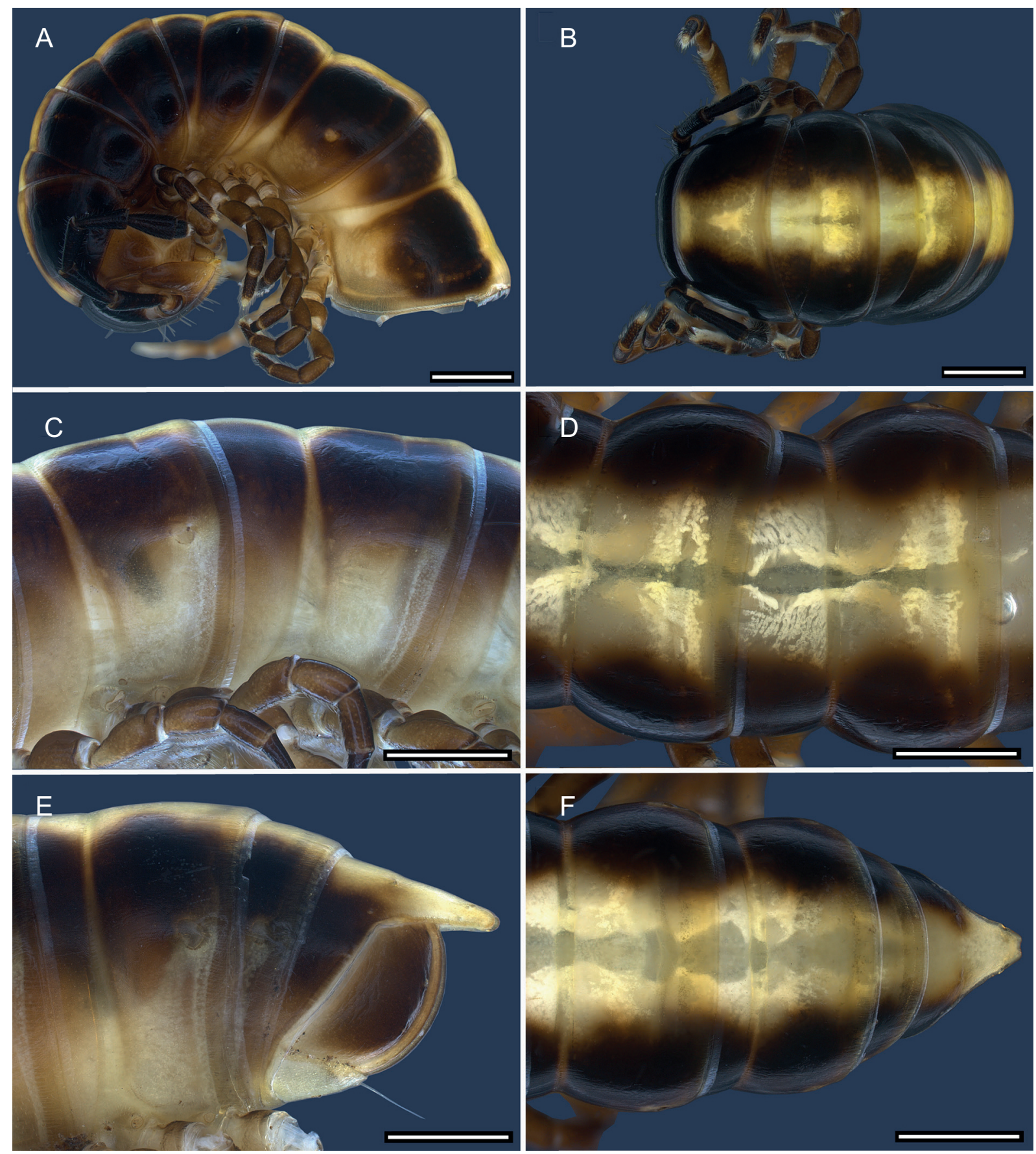

Fig. 12. Pogonosternum adrianae Jeekel, 1982, male from Moe-Walhalla Road (NMV K-12207). A-B. Anterior rings. A. Left lateral view. B. Dorsal view. C-D. Rings 10 and 11. C. Left lateral view. D. Dorsal view. E-F. Posterior rings. E. Left lateral view. F. Dorsal view. Scale bars: $1 \mathrm{~mm}$. 


\section{Other material examined}

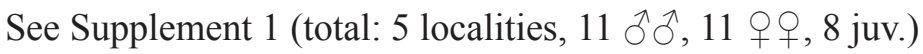

\section{Description}

MeAsurements. Length ca $2.6-2.8 \mathrm{~cm}$; midbody width ca $2.8-3.2 \mathrm{~mm}$.

Colouration. Colour in fresh material (Figs 12, 26B): margin of lateral edges of collum sometimes slightly lighter. Dorsum with broad median light yellowish brown stripe. On prozonites the trapezoidal paramedian light band slightly broader anteriorly, and on metazonites slightly broader posteriorly, broadest at 1/3 of length (Figs 12D, 26B). Flanks and area around ozopores slightly lighter (Fig. 12C).

STERNITES. No conspicuous sternal cones.

Legs. Male tarsal and tibial brushes present from legpair 1 to 7 , abruptly absent after. Female coxa of legpair 2 with pointed triangular process on caudal side directed distad, reaching $3 / 4$ of prefemur (Fig. $5 \mathrm{G}$ ).

Gonopods. Femorite $(F)$ long and slender (Fig. 13), narrowing towards prefemorite $(P F)$. Prolongation of femorite (prof) long, slender, S-shaped, proximal half directed posteriad and apical half directed distad. Femoral process $1(f p l)$ laminate, very long, subtriangular with pointed tip, slightly curved mesally, projecting distad of lateral process $(l p)$ and slightly distad of solenomere $(S)$. Femoral process $2(f p 2)$ very long, more slender than $f p 1$, whitish in colour, inflated, attached closely to $f p 1$; apex of $f p 2$ curved, not attached to $f p 1$, margin serrulate. Lateral process $(l p)$ on lateral side of prof, short, slender, directed distolaterally, not projecting distad of solenomere.

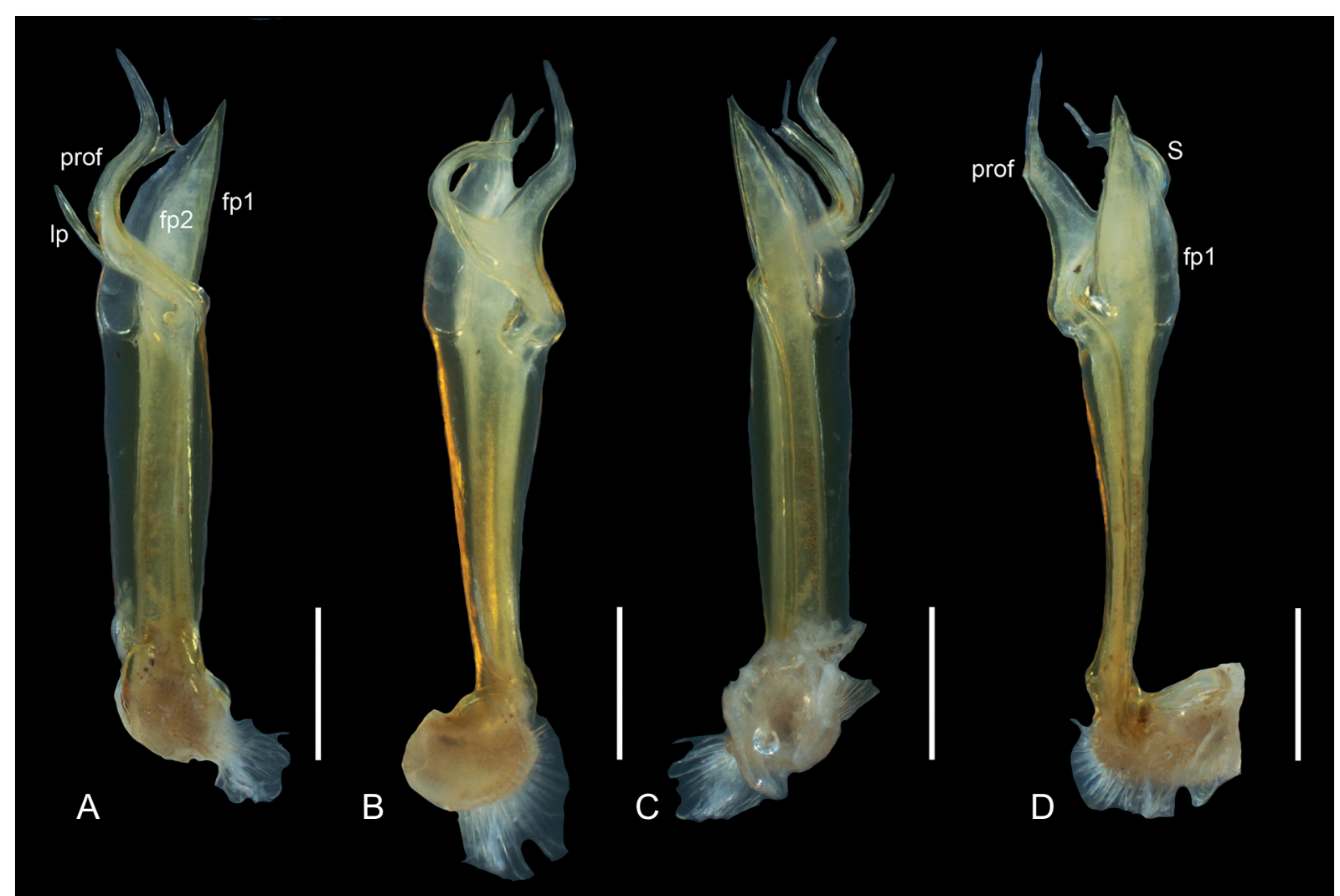

Fig. 13. Pogonosternum adrianae Jeekel, 1982, male, right gonopod (NMV K-10719). A. Posterior view. B. Lateral view. C. Anterior view. D. Mesal view. Scale bars $=0.5 \mathrm{~mm}$. 


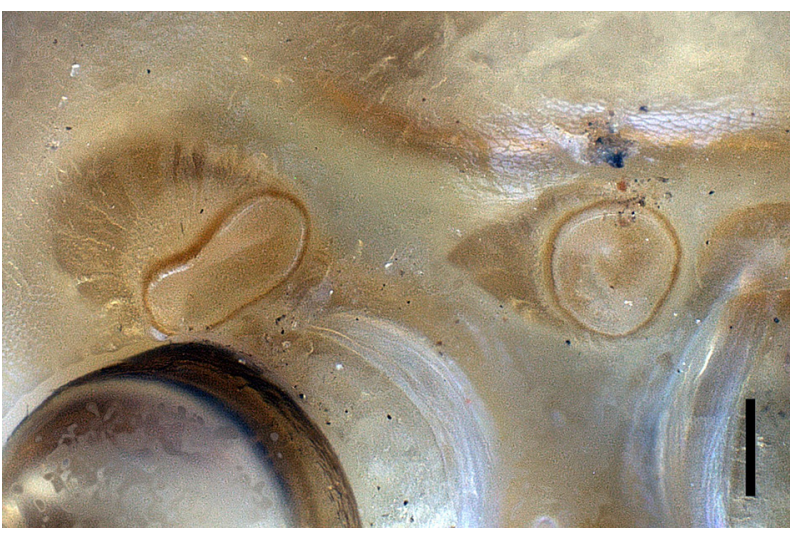

Fig. 14. Pogonosternum adrianae Jeekel, 1982, male, spiracles, midbody ring, left lateral side (NMV K-10719). Scale bar $=0.1 \mathrm{~mm}$.
SPIRACles. Anterior spiracles obliquely ovoid. Rim slightly raised and spiracular filter not protruding. Posterior spiracle ovoid with low rim, spiracular filter not protruding (Fig. 14).

\section{Distribution}

Strzelecki Ranges and central southern part of the Victorian Highlands (Fig. 7).

\section{Remarks}

A phylogenetic analysis (Decker 2016a) showed that this species is very closely related to $P$. laetificum with low genetic distances between populations of the two species.

We accept $P$. adrianae as a valid species because of its constant morphology, larger size and distinctive details of the gonopods ( $p r o f, f p 1, f p 2, F$ ), spiracles, dorsal colouration and process of female second leg 2 coxa, with no intermediate features between $P$. adrianae and $P$. laetificum noted.

\section{Pogonosternum laetificum Jeekel, 1982}

Figs $6 \mathrm{~A}, 7,15-17,26 \mathrm{C}$

Pogonosternum laetificum Jeekel 1982a: 203, fig. 1

Pogonosternum laetificum - Mesibov 2004: 42 (record). — Nguyen \& Sierwald 2013: 1159 (record). Decker 2016a: 16-25 (record, mention).

\section{Diagnosis}

Differs from other Pogonosternum species in having one lighter longitudinal stripe and no median darker stripe; from $P$. adrianae and $P$. montanum Decker, sp. nov., primarily by the small femoral process $2(f p 2)$ and the lateral process $(l p)$ being directed laterally, but also the presence of a rounded subtriangular, not pointed, process on the female leg 2 coxa; male tarsal and tibial brushes present from legpair 1 to 7-12; anterior spiracles obliquely ovoid with anterodorsally extended rim and spiracular filter not or slightly protruding.

\section{Material studied}

\section{Holotype}

AUSTRALIA: 1 ðे, Victoria, Ferntree Gully National Park, 18 km NNE of Dandenong, station 93, along nature track in temperate rainforest with tree ferns, under logs and litter and in rotting trees, 18 Nov. 1980, leg. C.A.W. Jeekel \& A.M. Jeekel-Rijvers (NBC).

\section{Paratypes}

AUSTRALIA: 3 우, same data as holotype (NBC).

\section{Other material examined}

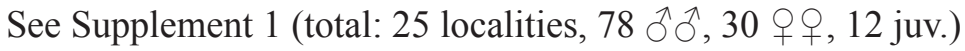




\section{Description}

MeAsuRements. Length ca 1.8-2.4 cm; midbody width ca 1.7-2.1 mm.

Colouration. Colour in fresh material (Figs 15, 26C): Margin of lateral edges of collum sometimes slightly lighter. Dorsum with broad median light yellowish brown stripe. On prozonites the trapezoidal paramedian light band slightly broader anteriorly, and on metazonites slightly broader posteriorly, nearly
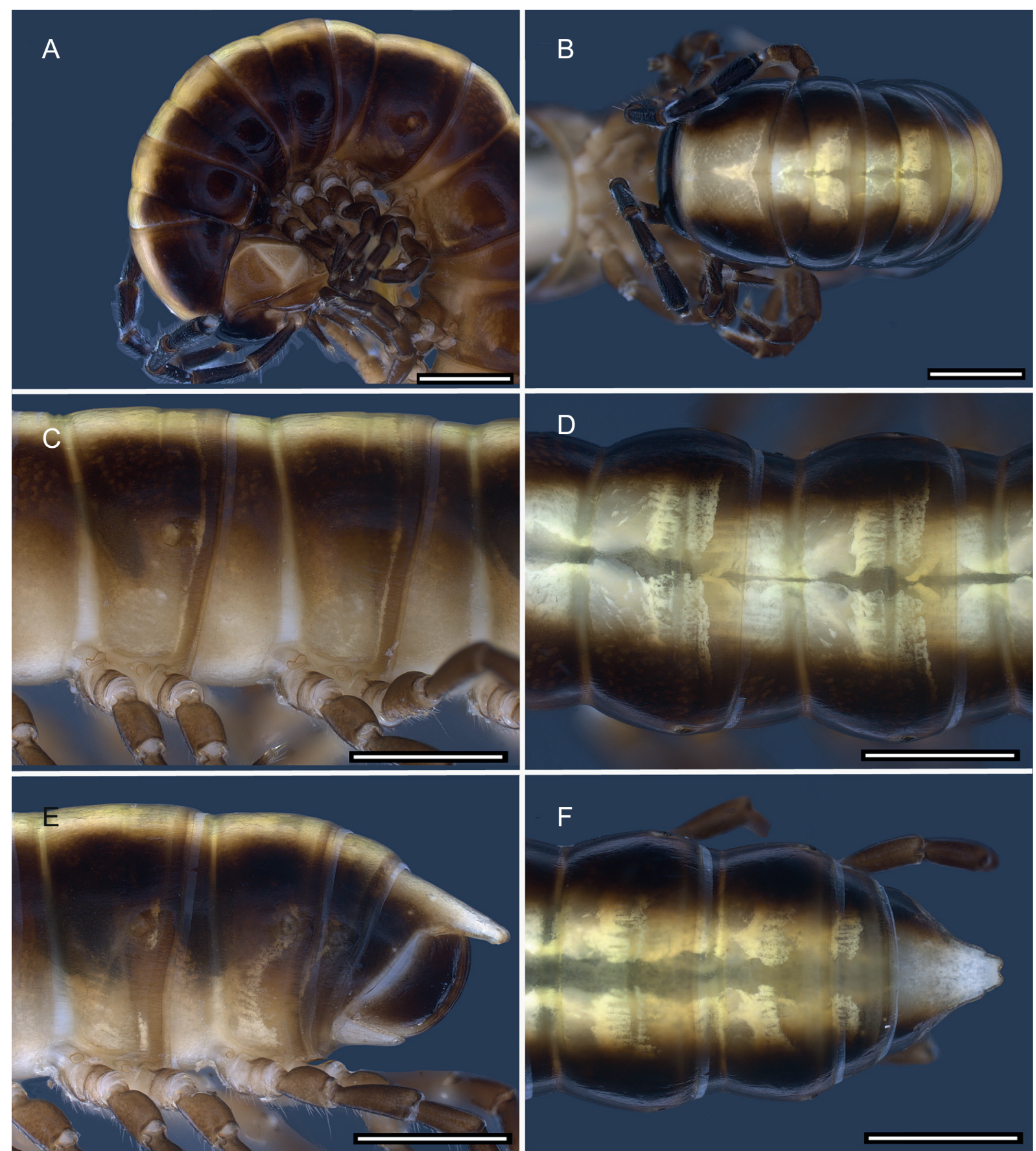

Fig. 15. Pogonosternum laetificum Jeekel, 1982, Õ, from Marysville, Mt Margaret Road (NMV K-12109). A-B. Anterior rings A. Left lateral view. B. Dorsal view. C-D. Rings 10 and 11. C. Left lateral view. D. Dorsal view. E-F. Posterior rings. E. Left lateral view. F. Dorsal view. Scale bars: $1 \mathrm{~mm}$. 
parallel, broadest at $4 / 5$ of length (Figs 15D, 26C). Flanks and area around ozopores slightly lighter (Fig. 15C).

STERNITES. No conspicuous sternal cones.

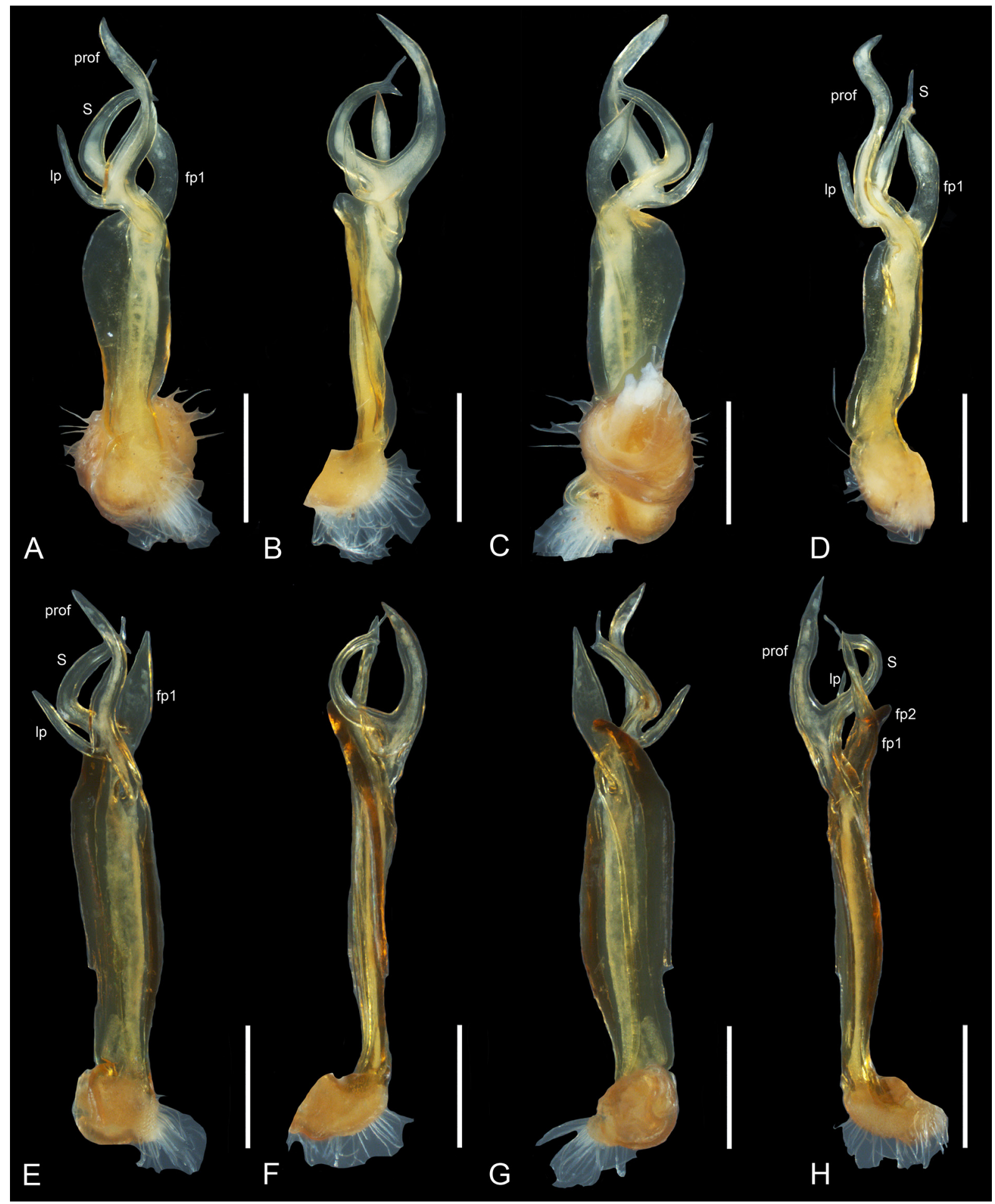

Fig. 16. Pogonosternum laetificum Jeekel, 1982, ð̊, right gonopod. A-D. ANIC 64-000049 from Cumberland Valley Reserve. E-H. NMV K10249 from Murrindindi River. A, E. Posterior view. B, F. Lateral view. C, G. Anterior view. D, H. Mesal view. Scale bars: $0.5 \mathrm{~mm}$. 
Legs. Male tarsal and tibial brushes present from legpair 1 to 7,9 or up to 12 thin out posteriorly, especially on tibia. Female coxa of leg 2 often with rounded process on caudal side directing posterordistad.

Gonopods. Considerable variability present (Fig 16). Femorite $(F)$ ranging from short and broad, dorsolaterally wider (Fig. 16A-D), to long and slender (Fig. 16E-H). Prolongation of femorite (prof) long, S-shaped. Femoral process $1(f p l)$ laminate, long, subtriangular to lozenge-shaped with pointed tip, projecting distad of lateral process $(l p)$ and reaching solenomere $(S)$. Shape of $f p 1$ ranging from laterally curved and not twisted (Fig. 16A-D) to more or less straight and twisted (Fig. 16E-H). Femoral process $2(f p 2)$ small, reduced to a knob or ridge-shaped structure. Lateral process $(l p)$ on lateral side of prof, short, slender, directed distolaterally, not projecting distad of solenomere.

SPIRACLES. Anterior spiracles distinctly obliquely ovoid. Rim raised with anterodorsal side broadly extended, not lobiform and spiracular filter not or slightly protruding. Posterior spiracle ovoid with low rim and spiracular filter not protruding (Fig. 17).

\section{Distribution}

Victorian Highlands north and east of Melbourne and northwestern Strzelecki Ranges (Fig. 7).

\section{Remarks}

There is no apparent geographical pattern to gonopod variation in P. laetificum (see also Decker 2016a). The distribution of male tarsal and tibial brushes often varies within a population at a single site.

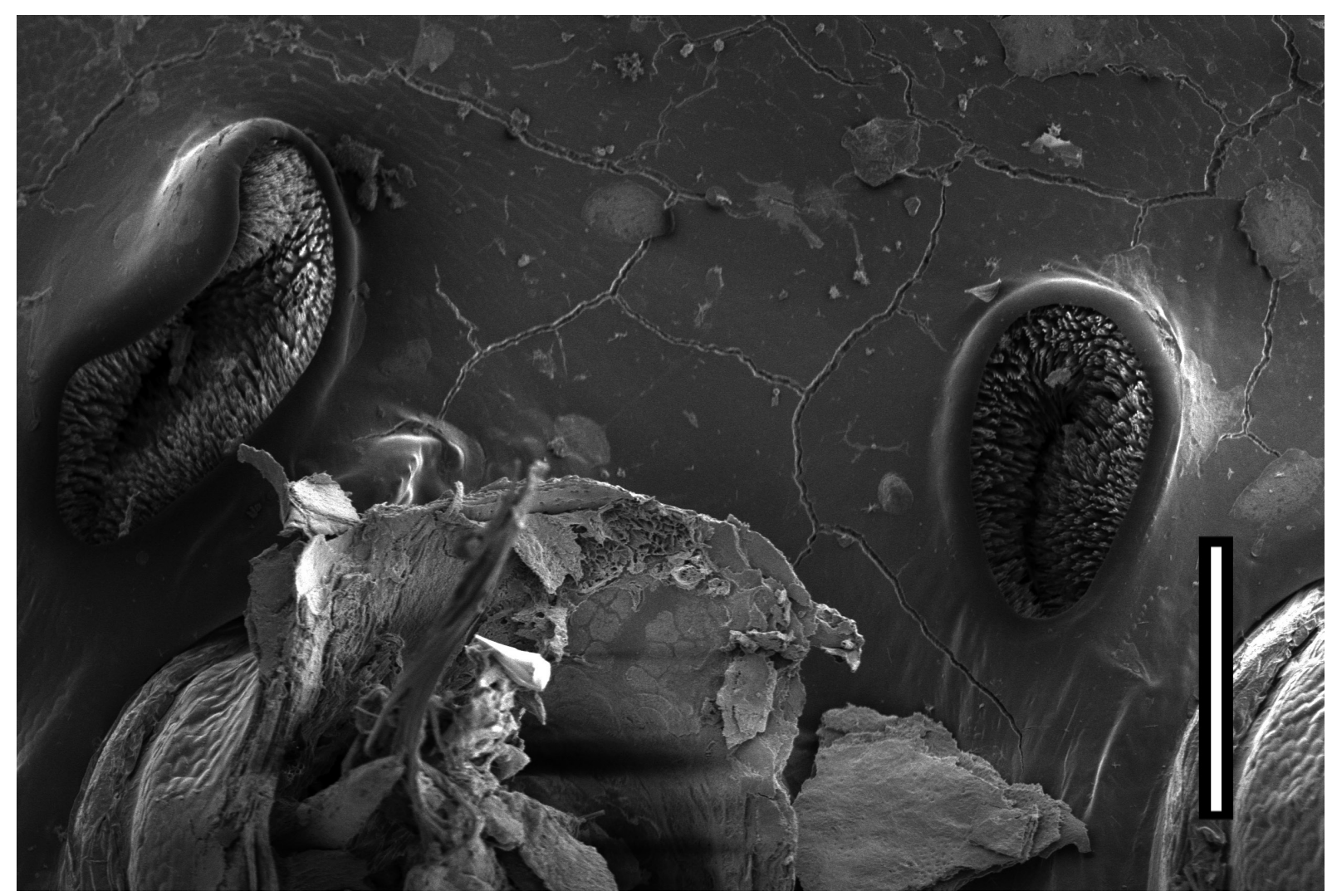

Fig. 17. Pogonosternum laetificum Jeekel, 1982, ð̃, spiracles, midbody ring, left lateral side (NMV K-9963). Scale bar: $0.1 \mathrm{~mm}$. 
Pogonosternum jeekeli Decker, sp. nov. urn:1sid:zoobank.org:act:D7334EB7-E36A-44CE-9ABA-D03FF08450AE

Figs $5 \mathrm{C}, 7,18-21,26 \mathrm{D}$

Pogonosternum sp. - Mesibov \& Churchill 2003: 3-7 (record, ecology). — Decker 2016a: 16 (record). Pogonosternum sp. A — Decker 2016a: 17-24 (record, mention).
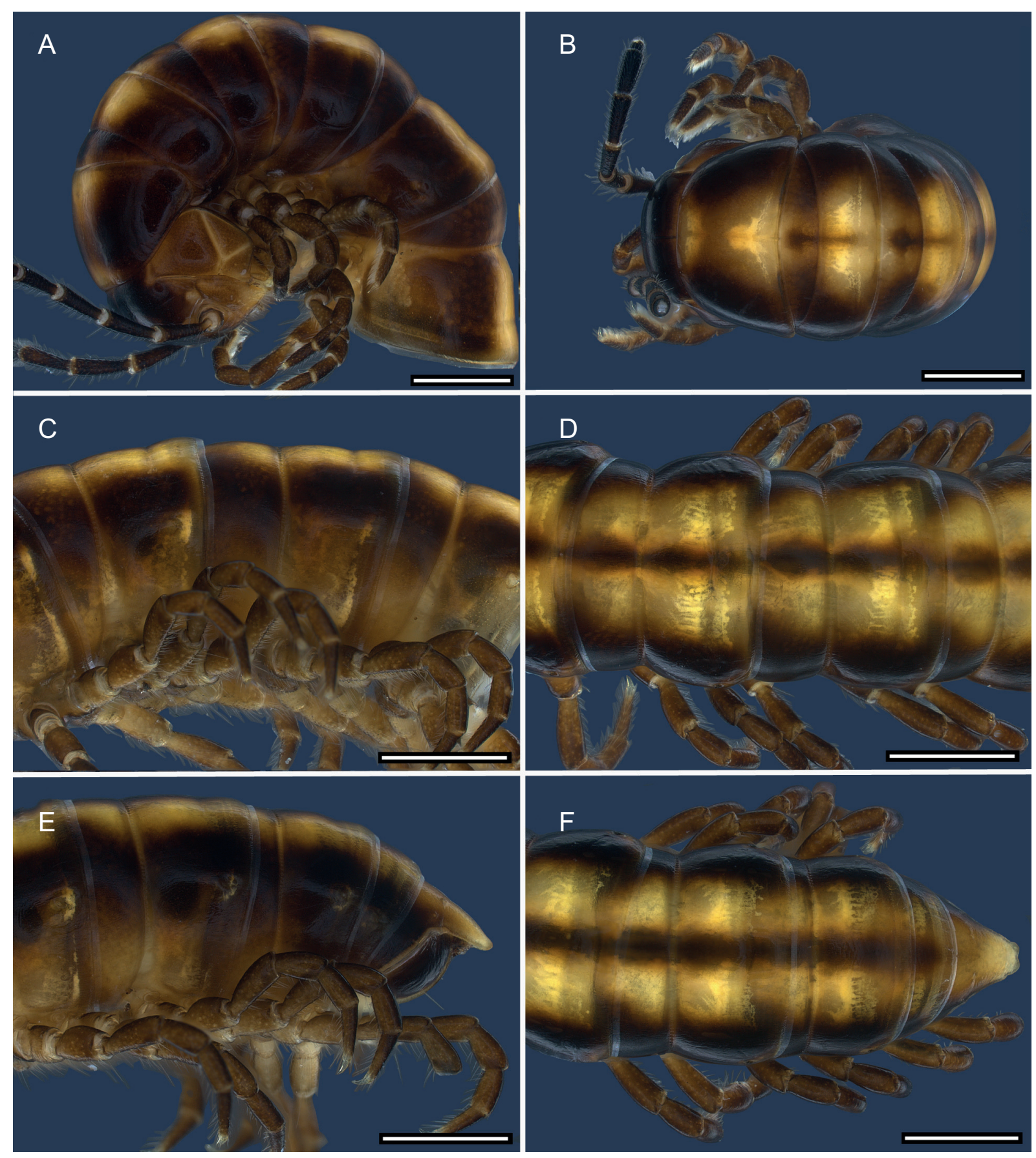

Fig. 18. Pogonosternum jeekeli Decker, sp. nov., ふ̂̉, holotype from Warby-Ovens National Park, Devenish-Wangaratta Road (NMV K-12178). A-B. Anterior rings. A. left lateral view. B. Dorsal view. C-D. Rings 10 and 11. C. Left lateral view. D. Dorsal view. E-F. Posterior rings. E. Left lateral view, F. Dorsal view. Scale bars: $1 \mathrm{~mm}$. 


\section{Diagnosis}

Differs from the other Pogonosternum species in having two lighter paramedian stripes and a median darker stripe; from $P$. nigrovirgatum, primarily by lateral process $(l p)$ often longer, reaching or projecting distad of most distal position of prolongation of femorite (prof), male tarsal and tibial brushes present to legpair 9, but prof never distinctly elongated and broadly curved.

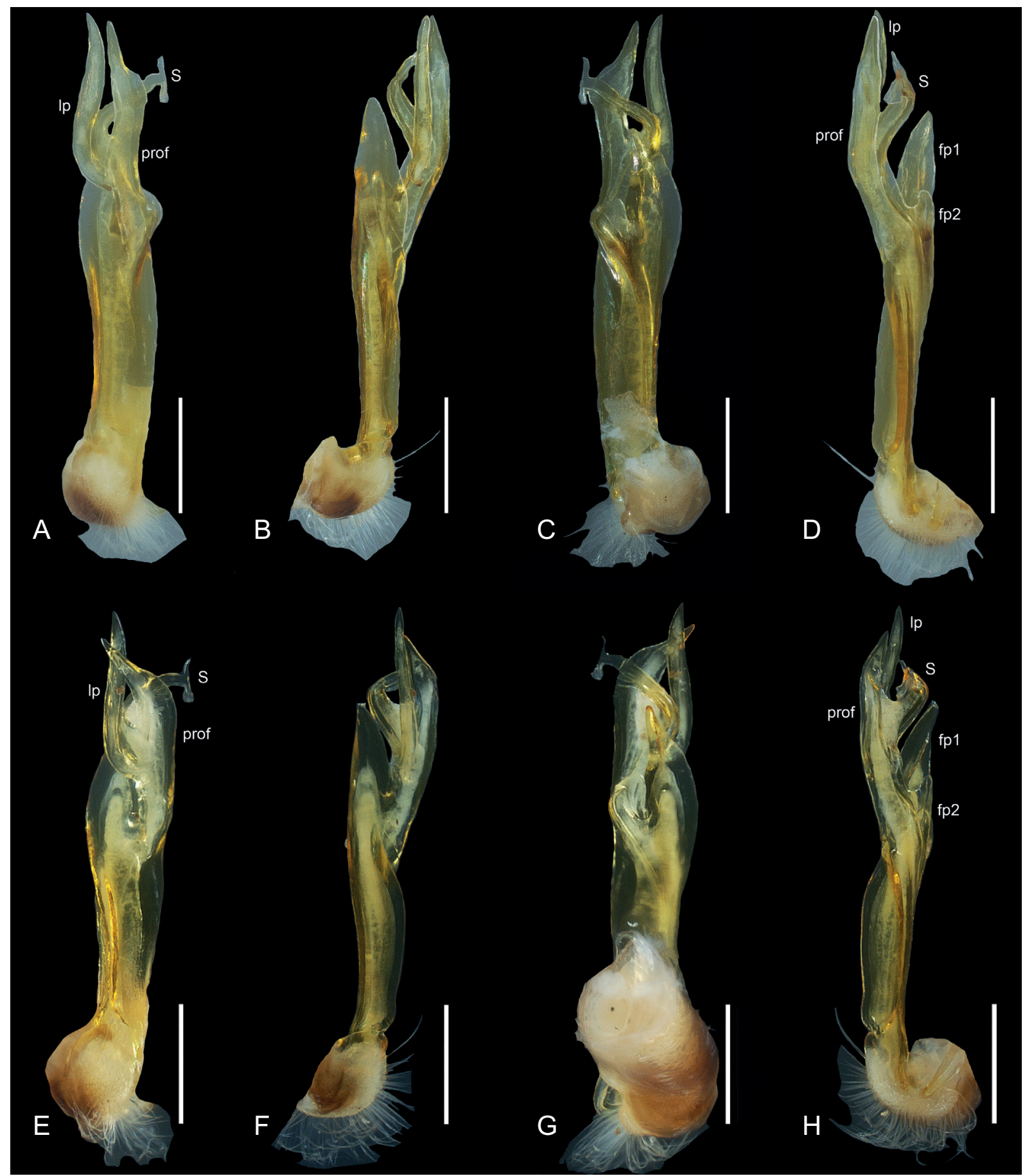

Fig. 19. Pogonosternum jeekeli Decker, sp. nov., ð̋, right gonopod. A-D. NMV K-10252 from Dyer Creek. E-H. NMV K-10250 from Bemm River. A, E. Posterior view. B, F. Lateral view. C, G. Anterior view. D, H. Mesal view. Scale bars: $0.5 \mathrm{~mm}$. 


\section{Etymology}

In honour of the Dutch myriapodologist Casimir A.W. Jeekel, who worked on the Australian paradoxosomatid fauna and described most of the previously known species of Pogonosternum.

\section{Material studied}

\section{Holotype}

AUSTRALIA: 1 o, Victoria, Warby-Ovens National Park, 8 km NE of Thoona, Devenish-Wangaratta Road, S22, 8 Aug. 2014, leg. P. Decker, R. Mesibov \& K. Voigtländer (NMV K-12178).

\section{Paratypes}

AUSTRALIA: $5 \hat{\jmath} \hat{\partial}$, same data as holotype (NMV K-13343-13347); $1 \hat{\jmath}$, same data as holotype (SMNG VNR017113); 1 ${ }^{\lambda}$, Victoria, Warby-Ovens National Park, 6 km N of Glenrowan, Taminick Gap

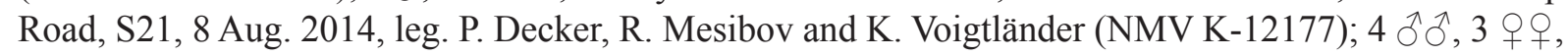
same data as preceding material (NMV K- K-13326-13342); 1 §, Victoria, Warby-Ovens National Park, 9 km NE of Thoona, Ridge Road, S23, 8 Aug. 2014, leg. P. Decker, R. Mesibov and K. Voigtländer (NMV K-12179).

\section{Other material examined}

See Supplement 1 (total: 38 localities, $62 \hat{\jmath} \partial, 30$ q $\propto, 33$ juv.)

\section{Description}

MeAsurements. Length ca 1.7-2.5 cm; midbody width ca $1.8-2.4 \mathrm{~mm}$.

Colouration. Colour in fresh material (Figs 18, 26D): margin of lateral edges of collum sometimes slightly to distinctly lighter (Fig. 18B). Dorsum with 2 paramedian light yellowish brown stripes and darker median brown stripe. On prozonites the trapezoidal paramedian light band slightly broader anteriorly, and on metazonites slightly broader posteriorly, broadest at 1/3 of length (Figs 18D, 26D).
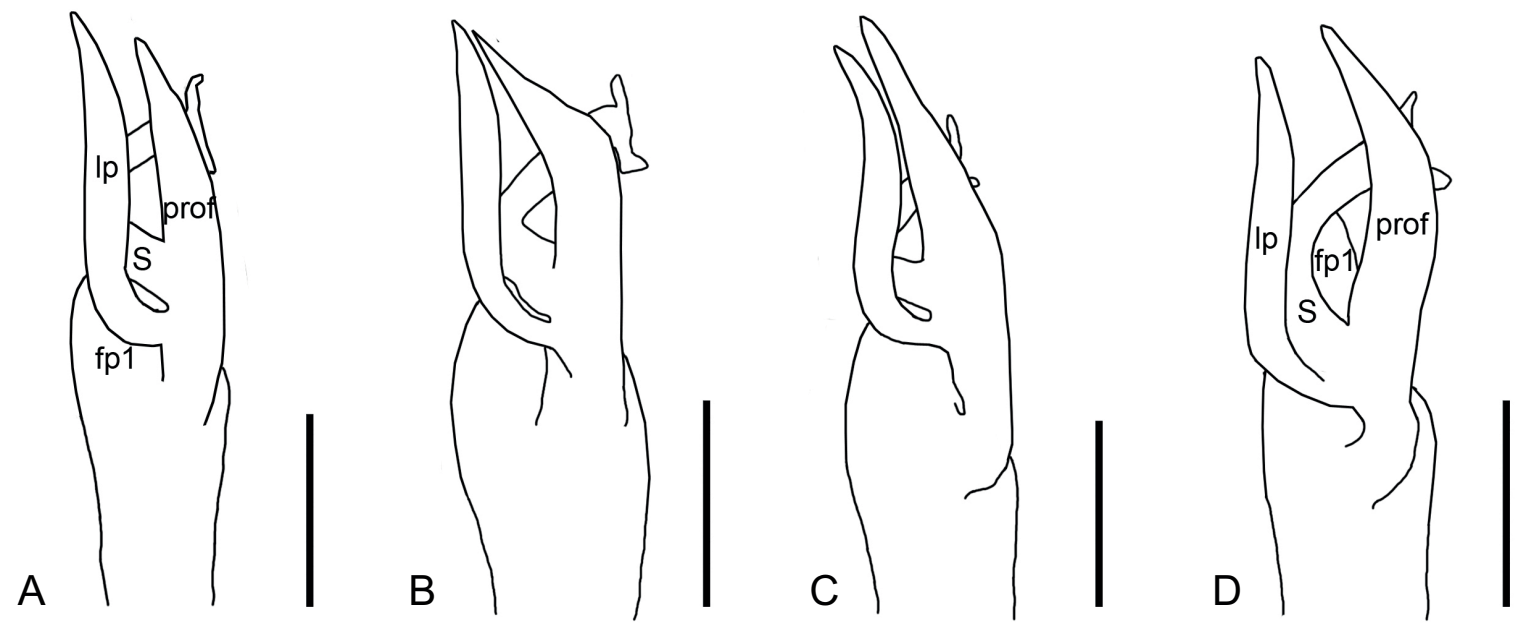

Fig. 20. Pogonosternum jeekeli Decker, sp. nov., đ̂, right gonopod, posterior view. A. NMV K-12178, holotype from Warby-Ovens National Park, Devenish-Wangaratta Road. B. NMV K-12195 from Cabbage Tree Palms Flora Reserve. C. NMV K-12197 from Buchan Caves Reserve. D. SMNG VNR016986 from Waterhouse Conservation Area. Scale bars: $0.5 \mathrm{~mm}$. 
Darker median stripe narrow to rhombic, broadest 3/4 of length on metazonites and prozonites. Flanks often distinctly lighter. Area around ozopores slightly to distinctly lighter, cloudy pale (Fig. 18C).

SteRnites. No conspicuous sternal cones.

LEgs. Male tarsal and tibial brushes present from legpair 1 to 9 , abruptly absent after.

Gonopods. Considerable variability present (Figs 19-20). Femorite $(F)$ moderately long and wide. Prolongation of femorite ( $p r o f$ ) long to very long, S-shaped. Apical part of prof rather short, directing nearly straightly distad (Fig 20A) to distolaterally curved, sometimes crossing lateral process ( $l p$ ) anteriad or posteriad to $l p$ (Fig. 19E-H). Apical part of prof often abruptly narrowing mesally (Figs 19, 20B). Femoral process $1(f p 1)$ laminate, moderate to long, moderately broadly subtriangular with more or less blunt tip, not reaching $l p$ and solenomere $(S)$. Femoral process $2(f p 2)$ small, knob-like to subtriangular. Lateral process $(l p)$ on lateral side of prof, moderate to long, laminate, directed distolaterally, tip often curved laterally, projecting distad of solenomere, projecting distad of (Figs 19, 20A) or nearly reaching prof.

SPIRACLES. Anterior spiracles distinctly obliquely ovoid. Rim raised with anterodorsal side often broadly extended, not lobiform and spiracular filter not or slightly protruding. Posterior spiracle ovoid with low rim and spiracular filter not protruding (Fig. 21).

\section{Ecology}

Pogonosternum jeekeli Decker, sp. nov. was mostly found in forests to $400 \mathrm{~m}$ a.s.1., but was also collected at ca $920 \mathrm{~m}$ a.s.l. and was found in pine plantations by Car (2010).

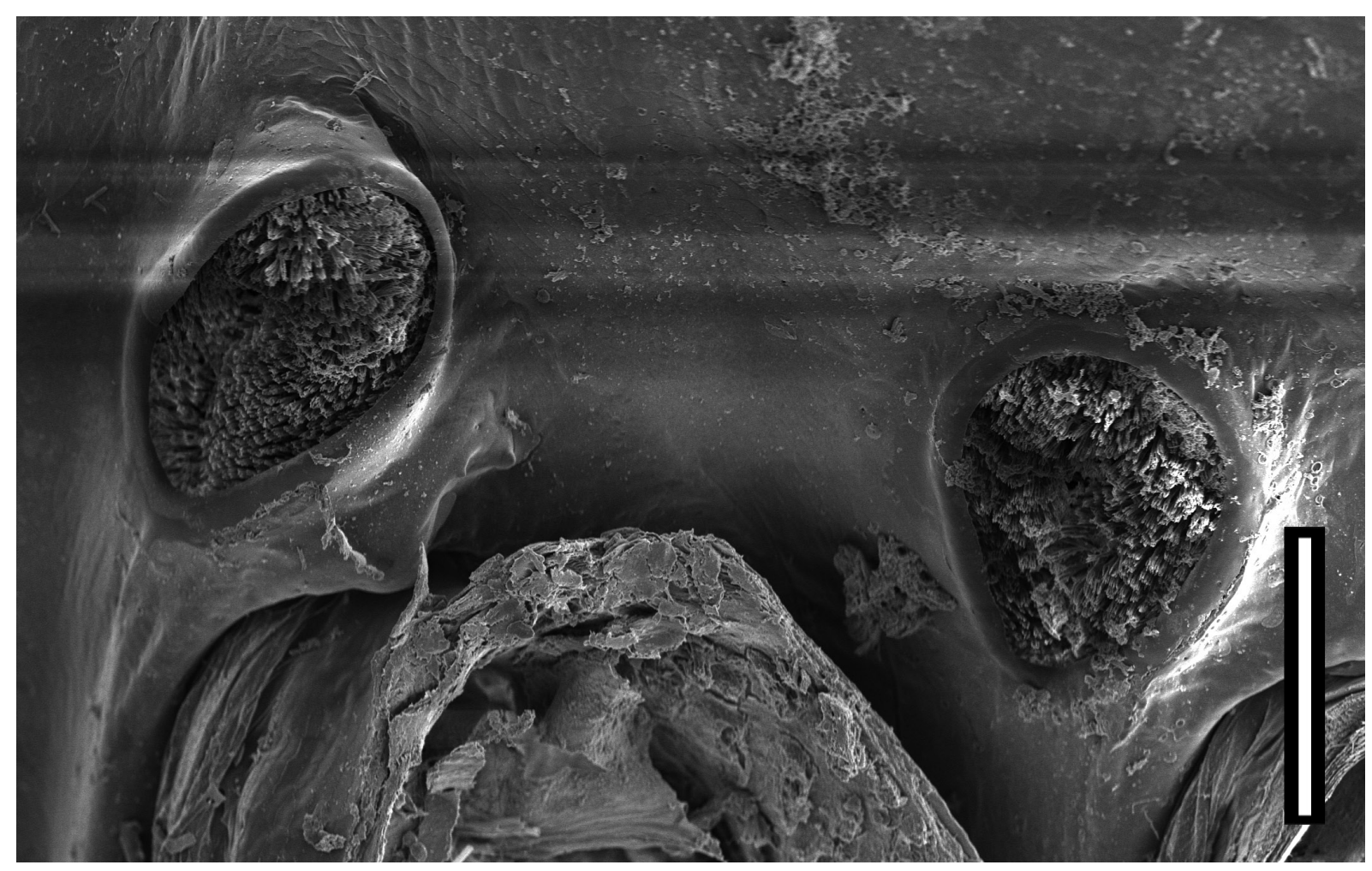

Fig. 21. Pogonosternum jeekeli Decker, sp. nov., $\widehat{\partial}$, spiracles, midbody ring, left lateral side (QM 23:15360). Scale bar: $0.1 \mathrm{~mm}$. 


\section{Distribution}

So far known from the northern and southern borders of the Great Dividing Range in eastern Victoria and southeastern New South Wales. Also recorded from Flinders Island and some islands of the Furneaux Group in the Bass Strait and in the northeastern corner of Tasmania (Fig. 7).

\section{Remarks}

There is no apparent geographical pattern to gonopod variation in P. jeekeli Decker, sp. nov. (see also Decker 2016a). Specimens from coastal central Gippsland, east of Orbost, and Tasmania are lighter in colour on the flanks than those from the higher elevated areas of the Australian mainland.

Pogonosternum montanum Decker, sp. nov. urn:1sid:zoobank.org:act:3DFA79E1-92A0-4155-B32A-16B88750E712

Figs $2 \mathrm{~A}, 4,5 \mathrm{H}, 7,22-25,26 \mathrm{E}$

Pogonosternum sp. 2 - Car 2010: 320 (record). — Decker 2016a: 16 (record).

Pogonosternum sp. B - Decker 2016a: 17-25 (record, mention).

\section{Diagnosis}

Differs from other Pogonosternum species in having one lighter longitudinal stripe and no median darker stripe; from $P$. adrianae and $P$. laetificum, primarily by the proximad bending femoral process $2(f p 2)$ and the lateral process $(l p)$ directed mesally, but also by the presence of a subtriangular, not pointed, process on the female leg 2 coxa; male tarsal and tibial brushes present from legpair 1 to 7; anterior spiracles obliquely ovoid with large lobiform anterodorsally extended rim and spiracular filter distinctly protruding.

\section{Etymology}

The name means "mountaineer" or "mountainous" in Latin and refers to this species' principal occurrences at higher elevations in the Australian Alps.

\section{Material studied}

\section{Holotype}

AUSTRALIA: 1 ô, New South Wales, 14 km NNE of Tumbarumba, Batlow Road, SW of Back Creek Road junction, S28, 9 Aug. 2014, leg. P. Decker, R. Mesibov and K. Voigtländer (NMV K-12184).

\section{Paratypes}

AUSTRALIA: $1 \hat{\jmath}$, same data as holotype (SMNG VNR 016993); $1 \hat{\jmath}$, same data as holotype (NMV K-13348); 1 ô, Victoria, 7 km SE of Holbrook, Mt Lawson State Park, S26, 9 Aug. 2014, leg. P. Decker, R. Mesibov and K. Voigtländer (NMV K-12182); 1 ð̂, Victoria, Mt Beauty, 29 Mar. 2000, leg. M. Burns (AMS KS106738).

\section{Other material examined}

See Supplement 1 (total: 17 localities, $80 \hat{\jmath}, 41$ q $q, 17$ juv.)

\section{Description}

MeAsurements. Length ca 1.7-2.3 cm; midbody width ca $1.9-2.2 \mathrm{~mm}$.

Colouration. Colour in fresh material (Figs 22, 26E): margin of lateral edges of collum sometimes slightly lighter. Dorsum with broad median light yellowish brown stripe. On prozonites the trapezoidal 
paramedian light band slightly broader anteriorly, and on metazonites slightly broader posteriorly, broadest at 1/3 of length (Figs 22D, 26E). Flanks and area around ozopores slightly lighter (Fig. 22C).

SteRnites. No conspicuous sternal cones.

LEGS. Male tarsal and tibial brushes present from legpair 1 to 7 , abruptly absent after. Female coxa of legpair 2 with subtriangular process on caudal side directed distad (Fig. 34).
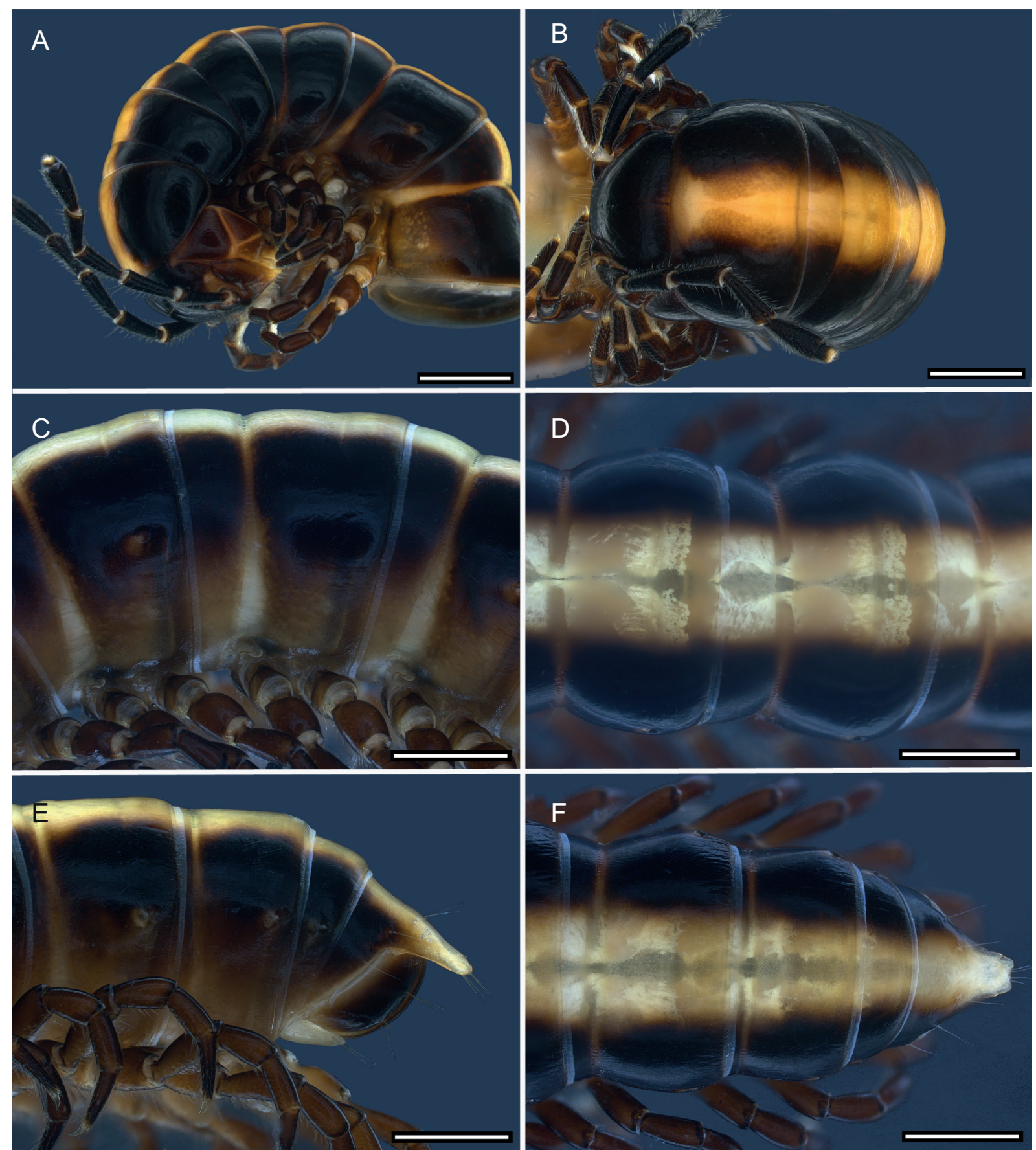

Fig. 22. Pogonosternum montanum Decker, sp. nov., $\hat{\jmath}$, from Batlow Road (NMV K-12184). A-B. Anterior rings A. Left lateral view. B. Dorsal view. C-D. Rings 10 and 11. C. Left lateral view. D. Dorsal view. E-F. Posterior rings. E. Left lateral view, F. Dorsal view. Scale bars: $1 \mathrm{~mm}$. 
Gonopods. Femorite $(F)$ short and broad (Figs 23-24). Prolongation of femorite (prof) long, S-shaped. Femoral process $1(f p l)$ laminate, long, subtriangular, slightly curved anteriad, not projecting distad of lateral process $(l p)$ and solenomere $(S)$. Femoral process $2(f p 2)$ short, slender, bent proximad. Lateral process $(l p)$ on mesal side of prof, short, laminate, directed mesally.

SPIRACLES. Anterior spiracles obliquely ovoid. Rim raised with anterodorsal side extended, distinctly lobiform and spiracular filter twisted and protruding. Posterior spiracle ovoid with low rim and spiracular filter mostly protruding (Figs 4A, 25).

\section{Ecology}

Pogonosternum montanum Decker, sp. nov. Decker was mostly found in mountain forests from 600 to $1110 \mathrm{~m}$ a.s.1. It also occurs in pine plantations (Car 2010 and new collections west of Tumbarumba, New South Wales) and was collected in coastal Central Gippsland near Bruthen (AMS KS.105106), where it is possibly introduced.

\section{Distribution}

Australian Alps in far eastern Victoria and far southeastern New South Wales and adjacent regions (Fig. 7).

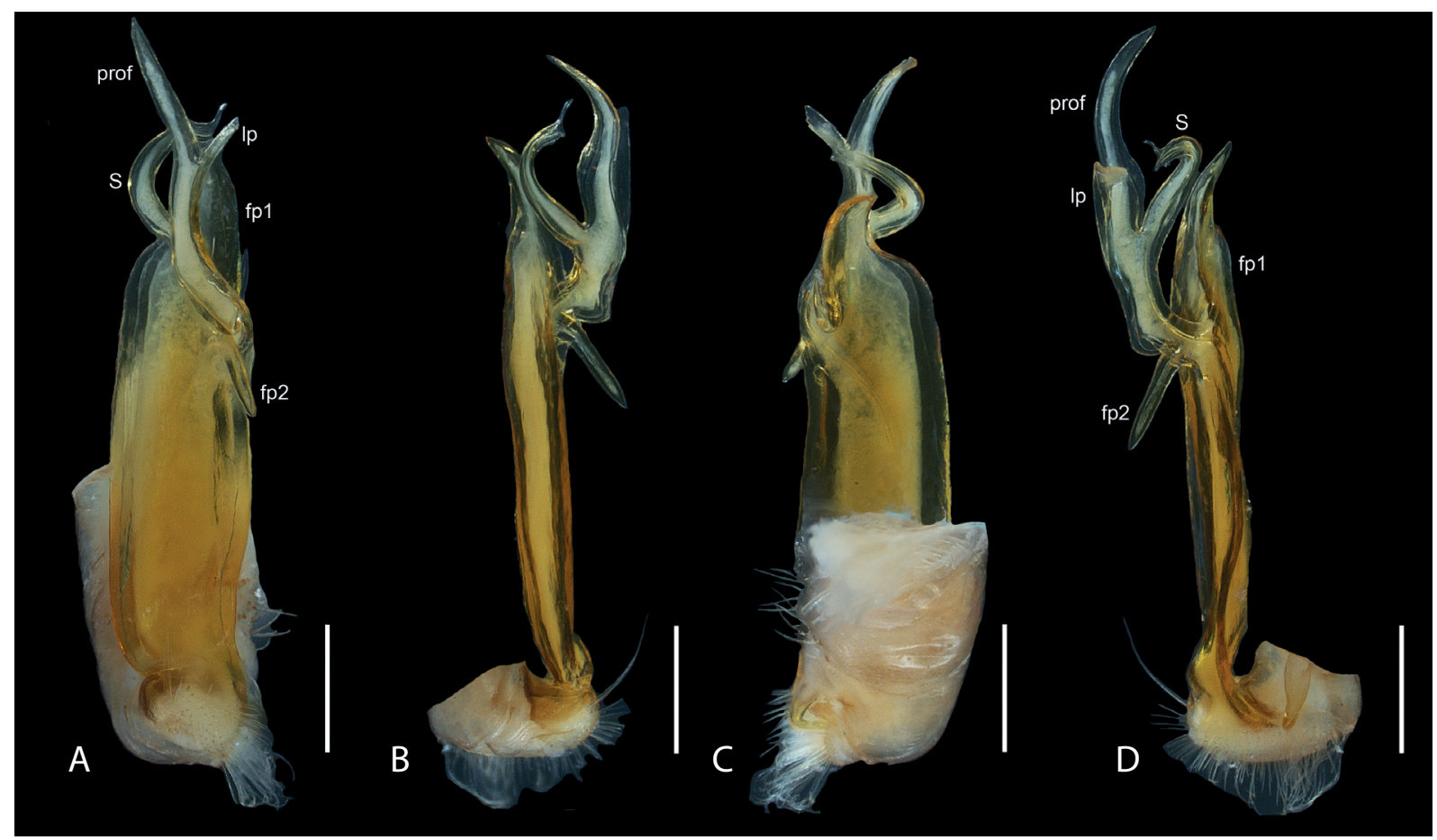

Fig. 23. Pogonosternum montanum Decker, sp. nov., §̂, paratype from Mt Beauty, right gonopod (AMS KS106738). A. Posterior view. B. Lateral view. C. Anterior view. D. Mesal view. Abbreviations: see Material and methods. Scale bars: $0.5 \mathrm{~mm}$. 

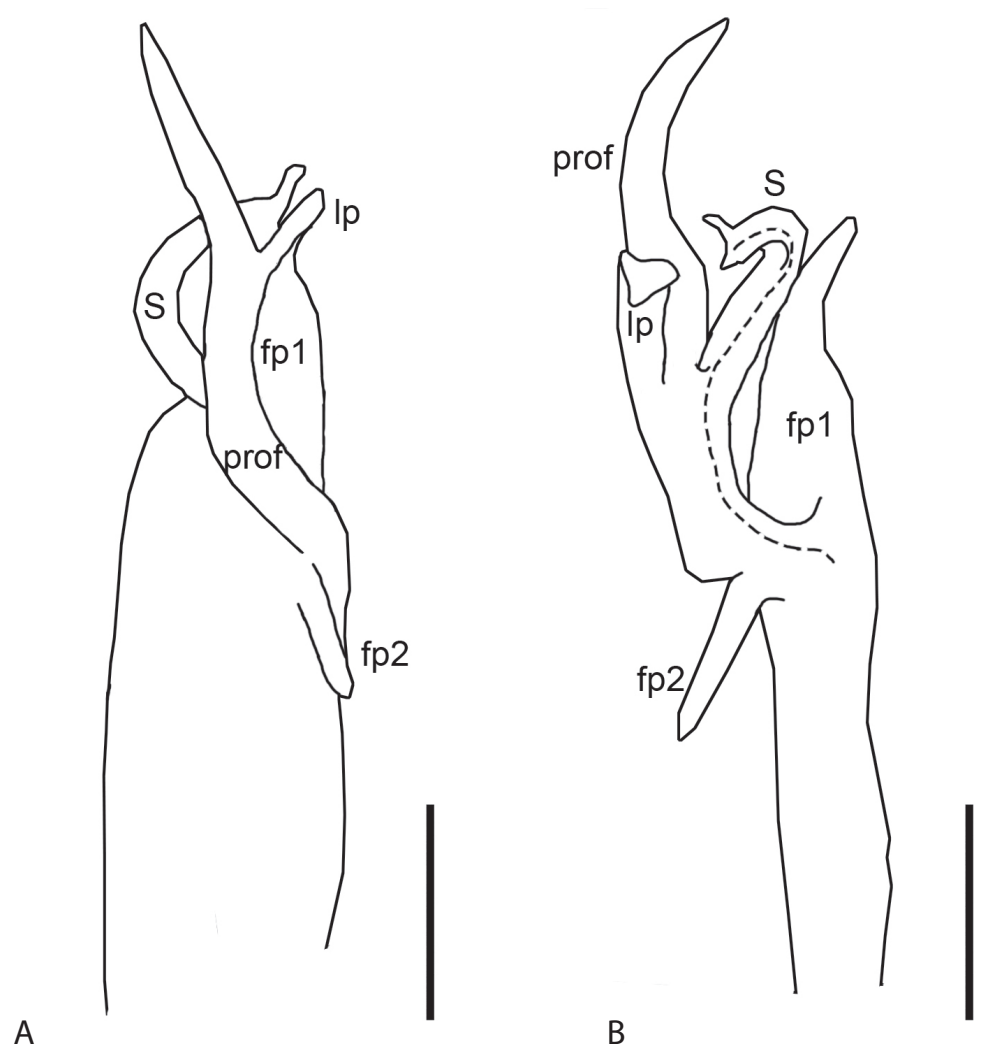

Fig. 24. Pogonosternum montanum Decker, sp. nov., §ิ paratype from Mt Beauty, right gonopod (AMS KS106738). A. Posterior view. B. Mesal view. Abbreviations: see Material and methods. Scale bars: $0.5 \mathrm{~mm}$.

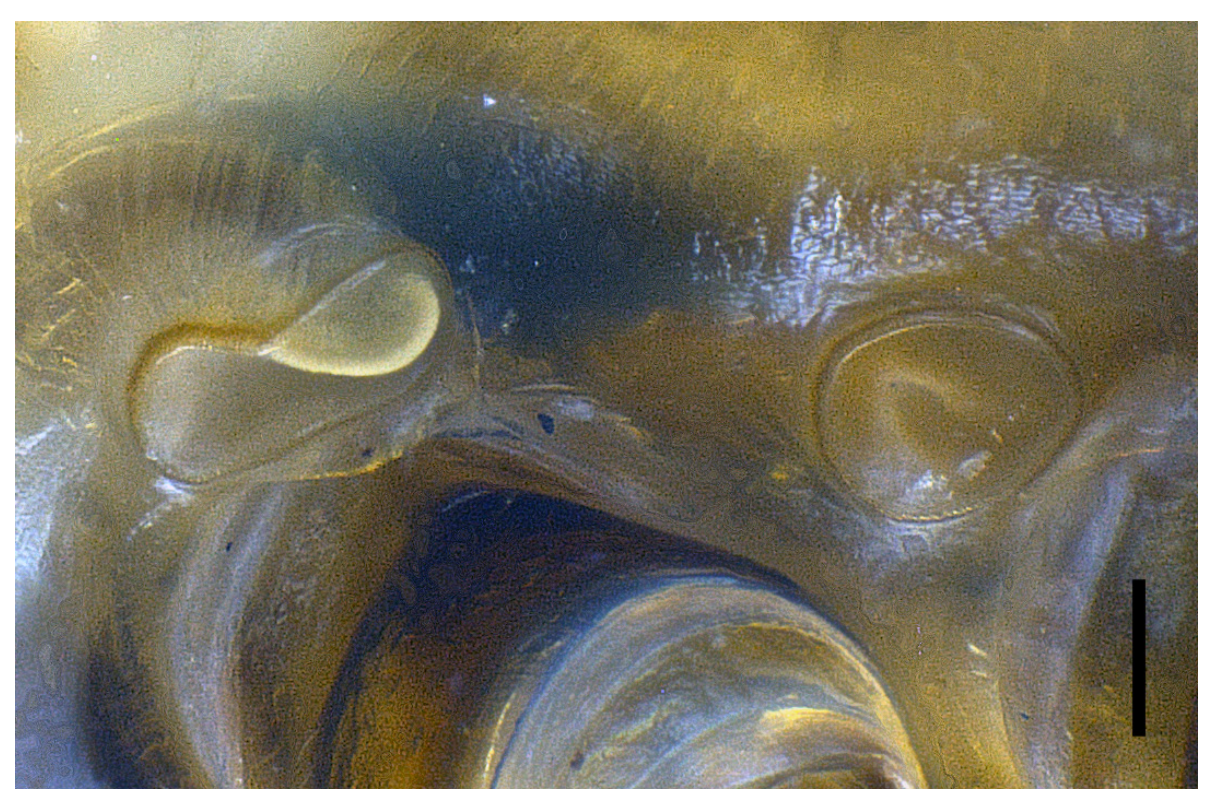

Fig. 25. Pogonosternum montanum Decker, sp. nov., $\widehat{\jmath}$, paratype, spiracles, midbody ring, left lateral side (NMV K-12184). Scale bar: $0.1 \mathrm{~mm}$. 


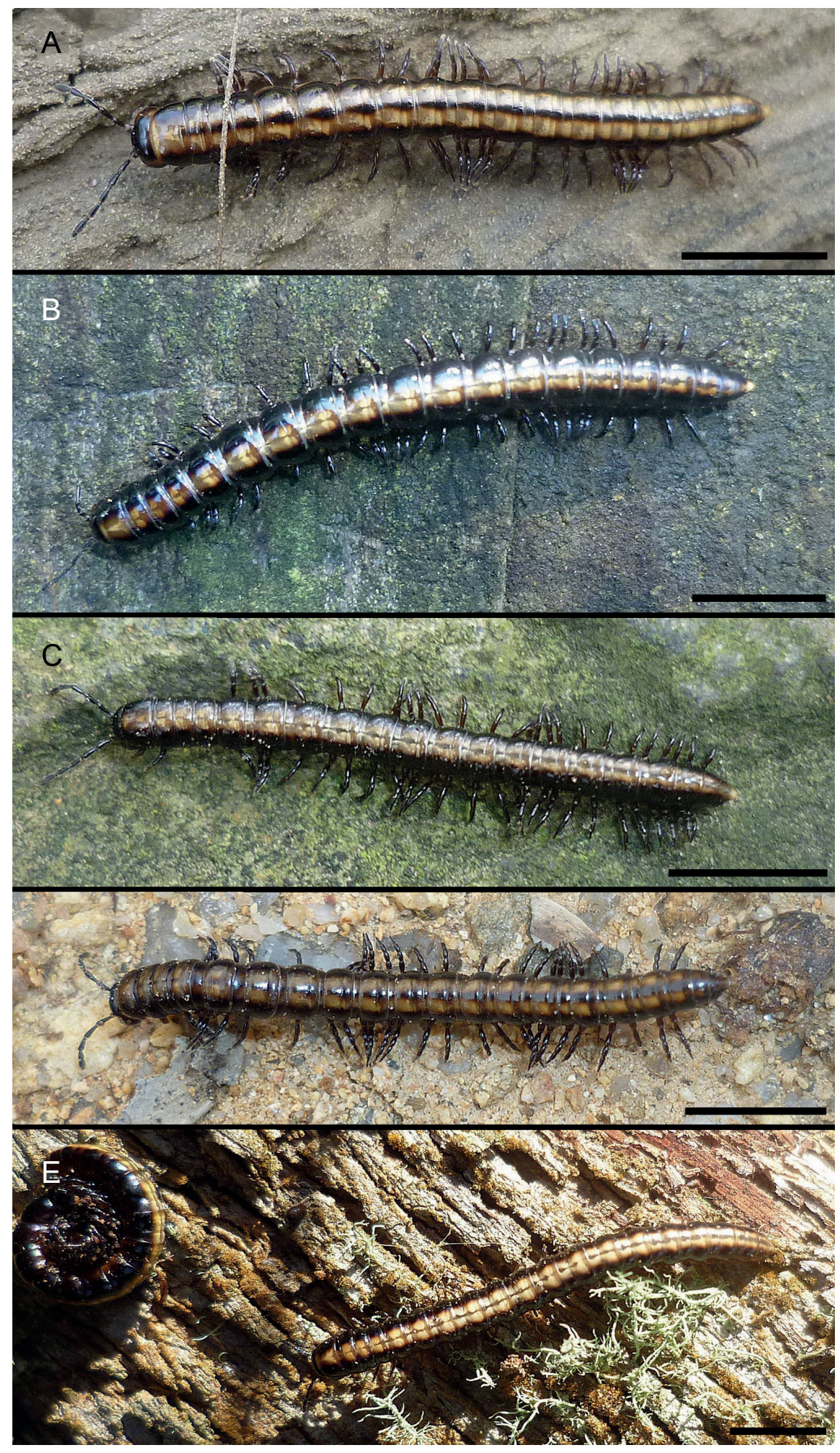

Fig. 26. Habitus and live colouration. A. Pogonosternum nigrovirgatum (Carl, 1902), $\widehat{\partial}$ from Adams Creek Nature Conservation Reserve (SMNG VNR016989). B. P. adrianae Jeeker, 1982, ô from Grand Ridge Road (NMV K-13349). C. P. laetificum Jeeker, 1982, ô from Toolangi State Forest, Two Hills Road. D. P. jeekeli Decker, sp. nov., ô from Warby-Ovens National Park, Taminick Gap Road. E. P. montanum Decker, sp. nov., $O^{\lambda}$ (left, NMV K-12183) and $\bigcirc$ (right, NMV K-13351) from Linden Roth Drive. Scale bars $=5 \mathrm{~mm}$. 


\section{Key to species of the genus Pogonosternum}

1. Dorsum with one median light band (Figs 12D, 15D, 22D). Femoral process 1 ( $f p l$ ) projecting distad of lateral process $(l p)$ (Figs 13, 16) or femoral process 2 ( $f p 2$ ) directed proximad (Figs 23, 24). .... 2

- Dorsum with two paramedian light bands, divided by a narrow darker stripe (Figs 8D, 18D). Femoral process $1(f p l)$ not projecting distad of lateral process $(l p)$ and femoral process $2(f p 2)$ small, directed distad (Figs 9-10)

2. Body larger: width over $3.0 \mathrm{~mm}$ (male ) or $3.2 \mathrm{~mm}$ (female). Femorite of gonopods elongate, slender. Gonopod process $f p 2$ (and $f p 1$ ) long and laminate, projecting distad of $l p$ (Fig. 13). Females with pointed process on coxa of legpair 2, reaching 3/4 of prefemur (Fig. 5G) . P. adrianae Jeekel, 1982

- Body smaller: width under $2.3 \mathrm{~mm}$ (male) or $2.7 \mathrm{~mm}$ (female). Femorite of gonopods not particularly elongate or slender. Gonopod process $f p 2$ short, not projecting distad of $l p$ (Figs 16, 23-24). Females with rounded process on coxa of legpair 2, reaching $1 / 4$ of prefemur (Fig. $5 \mathrm{H}$ )

3. Gonopod process $f p 1$ long, distinctly projecting distad of lateral process $(l p)$ and $f p 2$ short, knoblike, directed proximad, $l p$ directed mesad (Fig. 16). Male tarsal and tibial brushes present to legpair $8-12$

P. laetificum Jeekel, 1982

- Gonopod process $f p 1$ short, not projecting distad of $l p$ and $f p 2$ slender, curved, directed proximad, $l p$ directed laterad (Figs 23, 24). Male tarsal and tibial brushes present to legpair 7

P. montanum Decker, sp. nov.

4. Lateral process $(l p)$ short or medium sized, not reaching or projecting distad of most distal position of prolongation of femorite (prof) (Figs 9-10). Male tarsal and tibial brushes present to legpair 7, when prof not elongated (Fig. 9A-D); sometimes present to legpair 9, when prof distinctly elongated and broadly curved (Fig. 9E-H)

P. nigrovirgatum (Carl, 1912)

- Lateral process $(l p)$ long, nearly reaching or projecting distad of most distal position of prolongation of femorite (prof) (Figs 19-20). Male tarsal and tibial brushes always present to legpair 9, prof not elongated and broadly curved

P. jeekeli Decker, sp. nov.

\section{Discussion}

This study presents the fourth Australian paradoxosomatid genus to be revised using modern techniques and numerous specimens from various localities following the 'exploratory era' in which European taxonomists established genera based on a few specimens: Antichiropus (Attems 1911; Car et al. 2013; Car \& Harvey 2014), Dicladosomella Jeekel, 1982 (Jeekel 1982b; Car 2015), Oncocladosoma Jeekel, 1985 (Jeekel 1985; Decker 2016b), Pogonosternum (Carl 1902; Jeekel 1965; Decker 2016a). Moreover, this is the second study on Australian Paradoxosomatidae that uses molecular data to support taxonomic decisions based on morphology; a similarly integrative revision of the South Australian genus Oncocladosoma revealed this taxon to be a junior synonym of Somethus Chamberlin, 1920 (Decker 2016). Furthermore, high variability in gonopod morphology and haplotype diversity was found in South Australian Somethus species, just as in Pogonosternum. Both revised genera show complex morphological and genetic patterns, which demonstrates the need for geographically comprehensive sampling and genetic approaches to detect both morphologically and genetically variable species and their distribution patterns, and to support species hypotheses, when revising other Australian paradoxosomatid genera. Larger studies of this kind would also lead to a better understanding of speciation, dispersal and (glacial) retraction processes; establish the most useful morphological features for determination; and locate short-range endemics and biodiversity hotspots for conservation purposes. 


\section{Acknowledgements}

For loans of types and other material we are very grateful to Peter Lillywhite and Catriona McPhee (NMV), Graham Milledge (AMS), Beth Mantle (ANIC), Karen van Dorp (NBC), Judy Rainbird (QVMAG), and Peter Schwendinger (GMNH). Birgit Lang (SMNG) kindly provided help with taking SEM images. Cathy Car (Perth) and two anonymous reviewers provided suggestions on the draft manuscript. The field trip of P. Decker was financially supported by the 'Förderkreis Naturkundemuseum Görlitz'.

\section{References}

Akkari N. \& Enghoff H. 2011. On some surface structures of potential taxonomic importance in families of the suborders Polydesmidea and Dalodesmidea (Polydesmida, Diplopoda). ZooKeys 156: 1-24. http://dx.doi.org/ 10.3897/zookeys.156.2134

Attems C. 1911. Myriopoda exkl. Scolopendridae. In: Michaelsen W. \& Hartmeyer R. (eds) Die Fauna Südwest-Australiens. Ergebnisse der Hamburger südwest-australischen Forschungsreise 19053 (6): 147-204. Verlag von Gustav Fischer, Jena.

Attems C.M.T. 1914. Die indo-australischen Myriopoden. Archiv für Naturgeschichte A 80 (4): 1-398.

Attems C.M.T. 1937. Myriapoda 3. Polydesmoidea I. Fam. Strongylosomidae. Das Tierreich. Eine Zusammenstellung und Kennzeichnung der rezenten Tierformen 68, Walter de Gruyter \& Co., Berlin \& Leipzig.

Brölemann H.W. 1916. Description of a new species of Myriapoda from New South Wales. Proceedings of the Linnean Society of New South Wales 40 (4): 683-684.

Car C.A. 2009. Keeled millipedes (Diplopoda: Polydesmida: Paradoxosomatidae) in New South Wales. General and Applied Entomology 38: 1-7.

Car C.A. 2010. Pine plantations and native millipedes (Diplopoda: Polydesmida: Paradoxosomatidae) in south-eastern New South Wales, Australia. Australian Journal of Entomology 49 (4): 317-323. http://dx.doi.org/10.1111/j.1440-6055.2010.00771.x

Car C.A. 2015. The millipede genus Dicladosomella (Diplopoda: Polydesmida: Paradoxosomatidae) from New South Wales, Australia with descriptions of 18 new species. Austral Entomology 55 (1): 63-99. http://dx.doi.org/10.1111/aen.12153

Car C.A., Wojcieszek J.M. \& Harvey M.S. 2013. The millipede genus Antichiropus (Diplopoda: Polydesmida: Paradoxosomatidae), part 1: redefinition of the genus and redescriptions of existing species. Records of the Western Australian Museum 28: 83-118. http://museum.wa.gov.au/sites/default/ files/WAMRecords_2013_28(2)_83to118_CARetal.pdf [accessed 30 Nov. 2016]

Car C.A. \& Harvey M.S. 2014. The millipede genus Antichiropus (Diplopoda: Polydesmida: Paradoxosomatidae), part 2: species of the Great Western Woodlands region of Western Australia. Records of the Western Australian Museum 29 (1): 20-77. http://dx.doi.org/10.18195/issn.0312$\underline{3162.29(1) .2014 .020-077}$

Carl J. 1902. Exotische Polydesmiden. Revue suisse de Zoologie 10: 563-679. http://dx.doi.org/10.5962/ bhl.part.13794

Chamberlin R.V. 1920. The Myriopoda of the Australian Region. Bulletin of the Museum of Comparative Zoology 64 (1): 1-269.

Decker P. 2016a. Phylogenetic analysis of the Australian trans-Bass Strait millipede genus Pogonosternum (Carl, 1912) (Diplopoda, Polydesmida, Paradoxosomatidae) indicates multiple glacial refugia in southeastern Australia. ZooKeys 578: 15-31. http://dx.doi.org/10.3897/zookeys.578.8052 
Decker P. 2016. Integrative taxonomic revision of the polymorphic flat-millipede genera Oncocladosoma and Somethus in South Australia (Diplopoda : Polydesmida : Paradoxosomatidae). Invertebrate Systematics 30: 201-218. http://dx.doi.org/10.1071/IS15047

Humphreys W.F. \& Shear W.A. 1993. Troglobitic millipedes (Diplopoda: Paradoxosomatidae) from semi-arid Cape Range, Western Australia: systematics and biology. Invertebrate Taxonomy 7: 173-195. http://dx.doi.org/10.1071/IT9930173

Jeekel C.A.W. 1965. A new genus and a new species of the family Paradoxosomatidae from Australia (Diplopoda, Polydesmida). Entomologische Berichten 25: 7-14.

Jeekel C.A.W. 1968. On the classification and geographical distribution of the family Paradoxosomatidae (Diplopoda, Polydesmida). Thesis, University of Amsterdam, Netherlands.

Jeekel C.A.W. 1981. Australian Expedition 1980; legit C.A.W. Jeekel and A.M.Jeekel - Rijvers. List of collecting stations, together with general notes on the distribution of millipedes in eastern Australia and Tasmania. Verslagen en Technische Gegevens van het Instituut voor Taxonomische Zoölogie 30: 1-59.

Jeekel C.A.W. 1982a. Millipedes from Australia, 2: Antichiropodini from Victoria (Diplopoda, Polydesmida, Paradoxosomatidae). Bulletin Zoölogisch Museum, Universiteit van Amsterdam 8 (24): 201-212.

Jeekel C.A.W. 1982b. Four new or little-known Australiosomatini from New South Wales (Diplopoda, Polydesmida, Paradoxosomatidae). (Millipedes from Australia, 3). Bijdragen tot de Dierkunde 52 (2): 137-154. http://www.repository.naturalis.nl/document/547736 [accessed 30 Nov. 2016]

Jeekel C.A.W. 1985. Millipedes from Australia, 5: Australiosomatini from South Australia, with a note on the status of Polydesmus innotatus Karsch, and first record of a second Mediterranean julid in Australia (Diplopoda: Polydesmida, Paradoxosomatidae and Julida, Julidae). Records of the South Australian Museum 19: 19-37. http://biodiversitylibrary.org/page/40817602 [accessed 30 Nov. 2016]

Jeekel C.A.W. 1987. Millipedes from Australia, 11: Australiosomatini from Queensland (Diplopoda, Polydesmida, Paradoxosomatidae). Beaufortia 37 (2): 11-41. http://www.repository.naturalis.nl/ document/548905 [accessed 30 Nov. 2016]

Jeekel C.A.W. 2006. Millipedes from Australia, 20: A new genus and two new species of Antichiropodini from Lord Howe Island (Diplopoda, Polydesmida, Paradoxosomatidae). Myriapod Memoranda 9: 65-72.

Mesibov R. 2004. A new genus of millipedes (Diplopoda: Polydesmida: Dalodesmidae) from wet forests in southern Victoria, with brief remarks on the Victorian Polydesmida. Memoirs of Museum Victoria 61 (1): 41-45.

Mesibov R. 2006-2016. Millipedes of Australia [online]. Available from http://www.polydesmida.info/ millipedesofaustralia/index.html [accessed 1 Feb. 2016]

Mesibov R. 2008. Diversity of Queensland Paradoxosomatid Millipedes (Diplopoda: Polydesmida: Paradoxosomatidae). Australian Entomologist 35 (1): 37-46.

Mesibov R. 2014. The Australian millipede Dicranogonus pix Jeekel, 1982 (Diplopoda, Polydesmida, Paradoxosomatidae): a species with and without paranota. ZooKeys 454: 29-39. http://dx.doi. org/10.3897/zookeys.454.8625

Mesibov R. \& Churchill T.B. 2003. Patterns in pitfall captures of millipedes (Diplopoda: Polydesmida: Paradoxosomatidae) at coastal heathland sites in Tasmania. Australian Zoologist 32 (3): 431-438. http://dx.doi.org/10.7882/AZ.2002.021

Müller C.H.G. \& Sombke A. 2015. Diplopoda - Sense Organs. In: Minelli A. (ed.) Treatise on ZoologyAnatomy, Taxonomy, Biology - The Myriapoda II: 181-235. Brill, Leiden. 
Nguyen A.D. \& Sierwald P. 2013. A worldwide catalog of the family Paradoxosomatidae Daday, 1889 (Diplopoda: Polydesmida). Check List 9 (6): 1132-1353. http://dx.doi.org/10.15560/9.6.1132

Rowe M. \& Sierwald P. 2006. Morphological and systematic study of the tribe Australiosomatini (Diplopoda: Polydesmida: Paradoxosomatidea: Paradoxosomatidae) and a revision of the genus Australiosoma Brölemann. Invertebrate Systematics 20: 527-556.

Shelley R.M., Sierwald P., Kiser S.B. \& Golovatch S.I. 2000. Nomenclator generum et familiarum Diplopodorum II. Pensoft Series Faunistica 20, Pensoft, Sofia.

Manuscript received: 12 May 2016

Manuscript accepted: 16 June 2016

Published on: 10 January 2017

Topic editor: Rudy Jocqué

Desk editor: Laurence Bénichou

Printed versions of all papers are also deposited in the libraries of the institutes that are members of the EJT consortium: Muséum national d'Histoire naturelle, Paris, France; Botanic Garden Meise, Belgium; Royal Museum for Central Africa, Tervuren, Belgium; Natural History Museum, London, United Kingdom; Royal Belgian Institute of Natural Sciences, Brussels, Belgium; Natural History Museum of Denmark, Copenhagen, Denmark; Naturalis Biodiversity Center, Leiden, the Netherlands. 